\title{
Spatial Structure of Youth Migration in Indonesia: Does Education Matter?
}

\author{
Meirina Ayumi Malamassam ${ }^{1}$ D
}

Received: 20 May 2020 / Accepted: 5 January 2022 / Published online: 3 February 2022

(C) The Author(s) 2022

\begin{abstract}
It is broadly understood that migration works in a selective way, particularly by age and education. However, little is known about the variation of the spatial structures of migration by educational background. Using migration data from Indonesia's 2000 and 2010 population censuses, this study examined the education-specific youth migration flows in Indonesia by highlighting interactions between origin and destination regions and examining factors contributing to the migration structure. Strong interactions were found amongst regions located in the same island or in close geographic proximity for all education levels. More dispersed patterns of origin-destination pairs were observed in tertiary-educated migration structure. The effects of economic opportunities appear to have had more pronounced effect in the migration structure of the least educated group. The findings highlight the increasing importance of rural areas in highly educated migration flows and the greater attractiveness of more developed regions for the lower educated migration structure. The spatial structures of education-specific youth migration flows reinforce the wide inequality gap in education and employment opportunities across regions in Indonesia.
\end{abstract}

Keywords Youth Migration · Education · Spatial Structure $\cdot$ Multiplicative Component Method $\cdot$ Indonesia

\section{Introduction}

Young adults in Indonesia are the main contributors to population redistribution within the country. One out of 10 Indonesians aged 20-24 years moved between districts in 2015, representing the highest mobility rate among all age groups (Muhidin, 2018). The country's peak migration in the young adulthood resembles a typical schedule of age-specific migration that also contains a low rate of child migration

Meirina Ayumi Malamassam

ayumi.malamassam@anu.edu.au

1 School of Demography, Australian National University, Canberra, Australia 
and gradually declining levels until retirement age (Rogers \& Castro, 1981). Young adult selectivity in migration flows can be viewed as the direct consequence of their life course pathways, such as pursuing higher education, entering the labour force, getting married and childbearing (McDonald et al., 2013).

Besides age, education is another important determinant in explaining migration. Higher levels of education are known to increase propensities to migrate (Bernard \& Bell, 2018). However, educational selectivity of migration may vary across regions, age groups and cultural backgrounds (Shryock \& Nam, 1965; Williams, 2009). For people living in rural areas, for instance, low- and middle-educated populations have shown high rates of migration. Their movements can be attributed to limited opportunities in origin areas and pressures to obtain higher incomes or more stable employment activities (Maddox, 2010).

Migration is argued to be geographically distinct since regions differ in their attraction, loss and retention of young people (Smith et al., 2014). Young migrants, in particular, have been highly attracted towards big cities. Career opportunities and regional differences in labour market returns have been the main factors in explaining this spatial pattern (He et al., 2016; Liu et al., 2017). Lifestyle amenities can be another crucial factor influencing the young population's spatial preferences (He et al., 2016). Educational background has also become a critical factor in migration direction. Regions that offer more extensive skilled job opportunities and occupational mobility have a greater ability to attract highly educated migrants (Fielding, 1992; Findlay et al., 2009; Liu et al., 2017; Venhorst et al., 2010). In addition, the rapid growth of informal sectors can be a major pull factor for low-educated migration to big cities (Jones et al., 2016; Suzuki \& Suzuki, 2016).

As a large archipelagic country of around 270 million persons residing in a wide array of social and cultural backgrounds as well as variations in regional education profiles, Indonesia provides a unique context for studying educationspecific migration flows. Demographic characteristics and spatial patterns of internal migration in Indonesia have been studied extensively (Rangkuti, 2016; Sukamdi \& Mujahid, 2015; Tirtosudarmo, 2009; Wajdi, Adioetomo, et al., 2017; Wajdi, Mulder, et al., 2017). Some studies have also explained the relationship between education background and migration in the country (Adioetomo et al., 2014; Bernard \& Bell, 2018; Jones et al., 2016; Muhidin, 2018). However, little is known about the variation of spatial patterns of migration by educational background. It is important to examine the underlying spatial structures of the education-specific migration flows since regions' abilities to attract and retain education-specific population groups have implications for their human capital accumulation (Bjarnason \& Edvardsson, 2017), Thus, by focusing on the young adult population as the group with the highest migration magnitude across all ages in this country, this study aimed to fill the gap in knowledge on the spatial structure of youth migration, particularly in the Indonesian context.

The following research questions were explored in this study. First, to what extent can the spatial structure of youth migration over time be explained by migrants' education background? Second, what are the underlying factors that explain the 
education-specific spatial structure of youth migration over time? Following Rogers et al. (2002), this study defines spatial structure of migration as a description of interregional migration flows that explains the relative push and pull factors of each region and identifies levels of spatial interactions between places. The examination of the links between education and the spatial structure of migration in Indonesia provides a foundation for a better understanding of the implications of migration for human capital accumulation across regions.

The next section discusses the literature on internal migration in Indonesia and spatial patterns of migration. Subsequently, the data and method used in this study are elaborated. Next, a descriptive analysis of origin-destination components by education level is presented, followed by an exploration of the interaction component of the spatial structure model. The following discussion outlines the underlying factors in the education-specific spatial structure within youth migration systems in Indonesia. The last section concludes the study.

\section{Literature Review}

\section{Internal Migration in Indonesia}

Internal migration dynamics in Indonesia can be explained by three major narratives. The first is the population resettlement due to state intervention in the form of a transmigration program that peaked in the early 1980s until the end of the 1990s (Charles-Edwards et al., 2016; Tirtosudarmo, 2009). This policy was the national government's attempt to reduce population pressure in Java Island and redistribute agricultural households to less densely populated regions. The second narrative is migration motivated by income differentials and employment divergence across regions (Charles-Edwards et al., 2016; Muhidin, 2018; Sukamdi \& Mujahid, 2015; Tirtosudarmo, 2009; Vidyattama, 2016). The population flows from this motive are mainly towards urban areas (Jones \& Mulyana, 2015). The third is the population mobility influenced by the cultural or social norms of communities or ethnic groups (Tirtosudarmo, 2009). Some highly mobile ethnic groups, such as Minang, Batak and Bugis, view migration as a rite of passage whereby young people leave their hometowns to seek knowledge and life experience or to earn a living elsewhere. Overall, migration in Indonesia is motivated mainly by family and economic factors (Muhidin, 2018). However, there has been an increasing trend in migration for education-related motives in recent years.

Nearly two-thirds of recent migrants were aged between 15 and 34 (Statistics Indonesia, 2016). It is also estimated that nearly one-half of young Indonesians have experienced spatial movements before age 30 (Muhidin, 2018). Figure 1 shows the schedule of migration by age in 2000 and 2010, with the latter showing a higher migration intensity in the early $20 \mathrm{~s}$. The peak age in migration in Indonesia is remarkably younger than that in many other countries (Charles-Edwards et al., 2017). In terms of education, migrants tend to be better educated than non-migrants (Adietomo et al., 2014; Sukamdi \& Mujahid, 2015). Indonesians 
Fig. 1 Age profile of recent migration in Indonesia, 2000 \& 2010. Source: Author's estimations based on data from Indonesian Population Census 2000

\& 2010

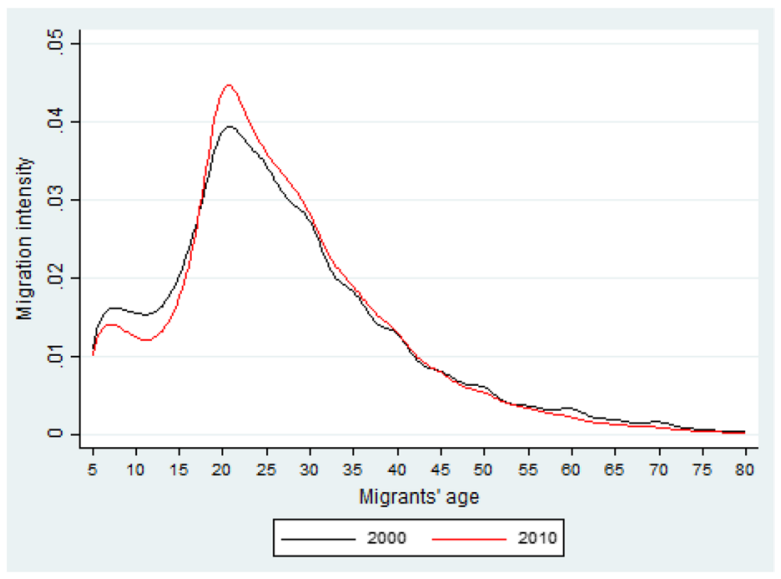

with a tertiary education degree, in particular, are 3.6 times more likely to move than their peers with no formal education (Bernard \& Bell, 2018). About $36 \%$ of migrants have the highest educational attainment of senior high school, whereas only $18 \%$ of non-migrants have a similar qualification. Moreover, $11.8 \%$ of migrants have a tertiary degree, and only $5 \%$ of non-migrants graduated from tertiary school.

There is a decreasing tendency of overall internal migration levels and a higher intensity of longer distance movement in Indonesia in recent years (Sukamdi \& Mujahid, 2015). Moreover, regions with the highest net youth migrants were all associated with the growth of Jakarta and its surrounding areas (Adietomo et al., 2014). The outer regions of Jakarta have become destination regions for highly educated migrants from Jakarta, while the capital city attracts a huge number of low-educated migrants from various provinces in Indonesia (Jones et al., 2016). Similarly, Wajdi, Adioetomo, et al. (2017) found that migration flows in Indonesia are mainly towards more developed regions, such as regions in Java Island. However, Java also acts as an important source of migrants and exhibits an increasingly negative net migration rate (Adioetomo et al., 2014). Increasing migration intensities towards the eastern part of Indonesia-regions that are considered less developed-have become the most noticeable trend of population mobility in recent years (Sukamdi \& Mujahid, 2015). Less developed regions are argued to offer accelerated career trajectories for the educated migrants because of their less competitive labour market amid the growth of knowledge-based sectors in the regions (Malamassam et al., 2018).

\section{Spatial Patterns of Education-specific Migration Flows}

Education is an important influence on the spatial patterns of internal migration. Less developed areas tend to send highly educated migrants to more developed areas 
(Corcoran et al., 2010; Whisler et al., 2008). The expansion of economic opportunities for skilled labourers increases regions' attractiveness for highly educated migrants. Hence, this situation implies a positive linkage between education and migration (Long, 1973). However, education may also work negatively towards migration when the constraint of finding work opportunities for low-educated individuals in their areas of origin push them to migrate (Gould, 1982). This situation may also drive rural to urban migration amongst low-skilled people. Education may also work as a motive for migration, particularly for pursuing tertiary degree. Although migration for pursuing tertiary education has not been a prominent feature of internal migration in many countries, this type of migration has a noticeable impact on the age and spatial structure of youth migration (Wilson, 2015). Not only is it concentrated mainly in a particular age group, but the spatial structure of tertiary student migration mostly involves movement from rural and small cities to metropolitan or provincial capitals.

Previous studies have emphasised the high intensity of highly educated migration to big cities that offer more skilled job opportunities and higher wages (He et al., 2016; Liu et al., 2017; Venhorst et al., 2010). However, in developing countries, a growth in skilled job opportunities is likely to be followed by the development of informal sectors. Thus, urban labour markets provide not only economic opportunities for skilled workers but also extensive low-skilled job opportunities (Suzuki \& Suzuki, 2016). This situation has resulted in migration towards urban areas by both the highest and the lowest educated individuals. While young migrants tend to move to regions near to their hometowns because of regional familiarity (Fafchamps \& Shilpi, 2013; Venhorst, 2013), highly educated migrants have higher propensities to make long-distance movements (Rosenbloom \& Sundstrom, 2004; Spring et al., 2016). In addition, the flows of highly educated migration have distinct geographical patterns from other types of mgration (Engbersen \& Snel, 2013). Moreover, rural-rural and urban-urban migrants are likely to be more highly educated than rural-urban migrants (Rebhun \& Brown, 2015).

While the pattern of urban-rural migration has substantial implications for rural development (Lomax et al., 2014), rural and remote areas are rarely discussed as popular destinations for young migrants. However, these areas may attract highly educated migrants with specialised qualifications, such as medicine, education or public service (Martel et al., 2013). Their skills and qualifications, along with the additional support provided by the government, may boost their careers and give them higher salaries. At the regional level, since this type of migration often features in-migrants with higher educational attainment than rural natives, this situation can help create more jobs in service sectors, extend social networks and accelerate economic growth in rural areas (Lomax et al., 2014). Unfortunately, graduates' migration to such areas are often for short time periods only, as migrants are motivated to secure their first entry to the workforce but plan to migrate elsewhere once they have settled in the labour market (Corcoran et al., 2010). On the other hand, young adults with low earning and less skilled professions are argued to have higher odds of migrating from urban to rural areas (Stockdale \& Catney, 2014), particularly during the life course stage of household formation. 


\section{Data}

This study used the full enumeration records of the 2000 and 2010 Indonesia population censuses along with subset samples for persons aged 15-34 years to represent the young adult population. This age range comes close to the legal definition of the youth population in Indonesia of 16-30.

Migrants are persons whose census region of residence was different to their region of residence five years earlier. The classification of regions in this study is an extension of Wajdi et al.'s (2015) work on classifying nearly 500 districts in Indonesia, including the urban-rural characteristics. The classification of metropolitan regions is based on the Indonesian Government's Mid-Term Development Plan 2015-2019 on Regional Development that includes eight metropolitan regions. The remaining districts are stratified according to geographical distribution, proportion of urban subdistricts and share of the urban population. The regional classification used in this study is illustrated in Fig. 2.

The distribution of youth migrants across regions in Indonesia over two censuses is presented in Table 1 . There were 4,553,363 young interregional migrants in 2000 , or about $6 \%$ of the total young population in Indonesia. In 2010 , the number of young migrants increased slightly to $4,569,146$, but the proportion decreased by $0.5 \%$. Most young migrants resided in metropolitan and urban areas, and only about one-quarter lived in rural areas. These patterns persisted between the two censuses. Further, regions in Java and Bali were consistently shown as major origin and destination regions in the country. The youth migrant population in metropolitan regions tended to decrease over the 10 years, while many urban and rural regions in other

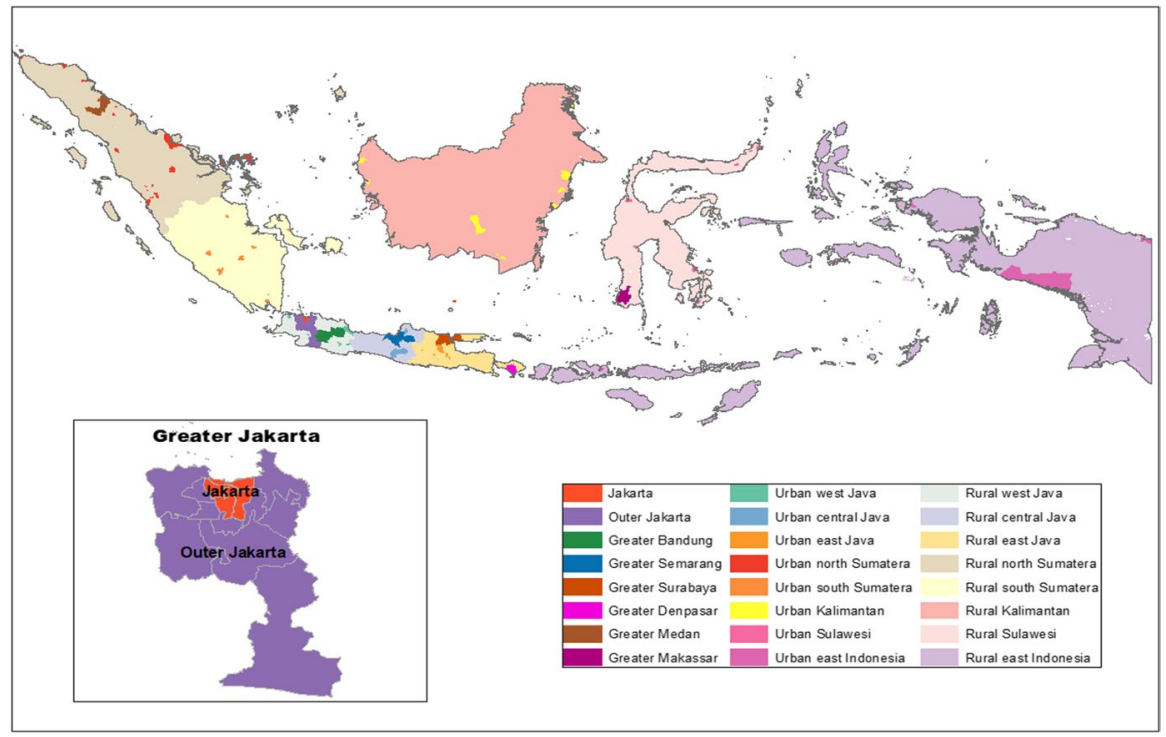

Fig. 2 Map of regional classification in Indonesia. Source: Author's own drawing, boundaries used are extracted from diva-gis.org 


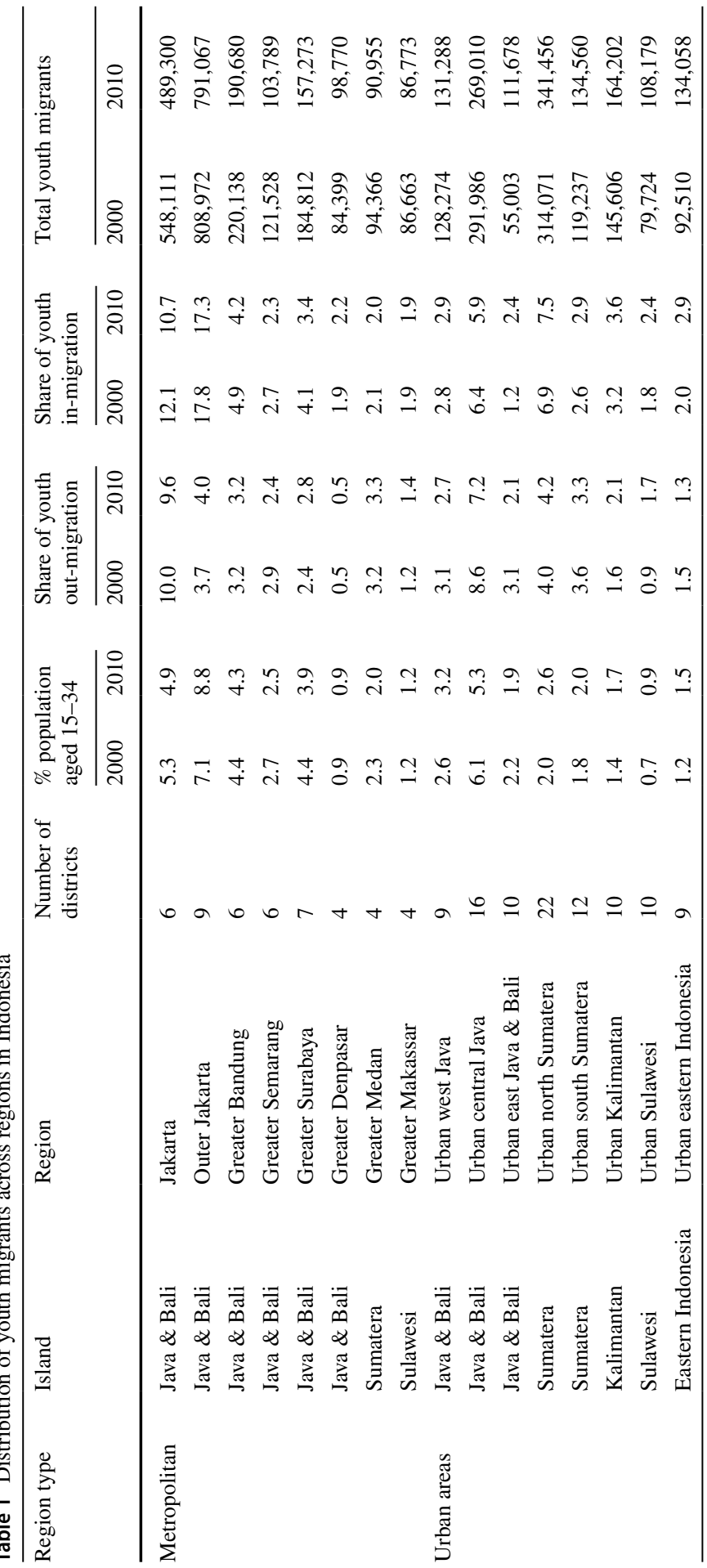




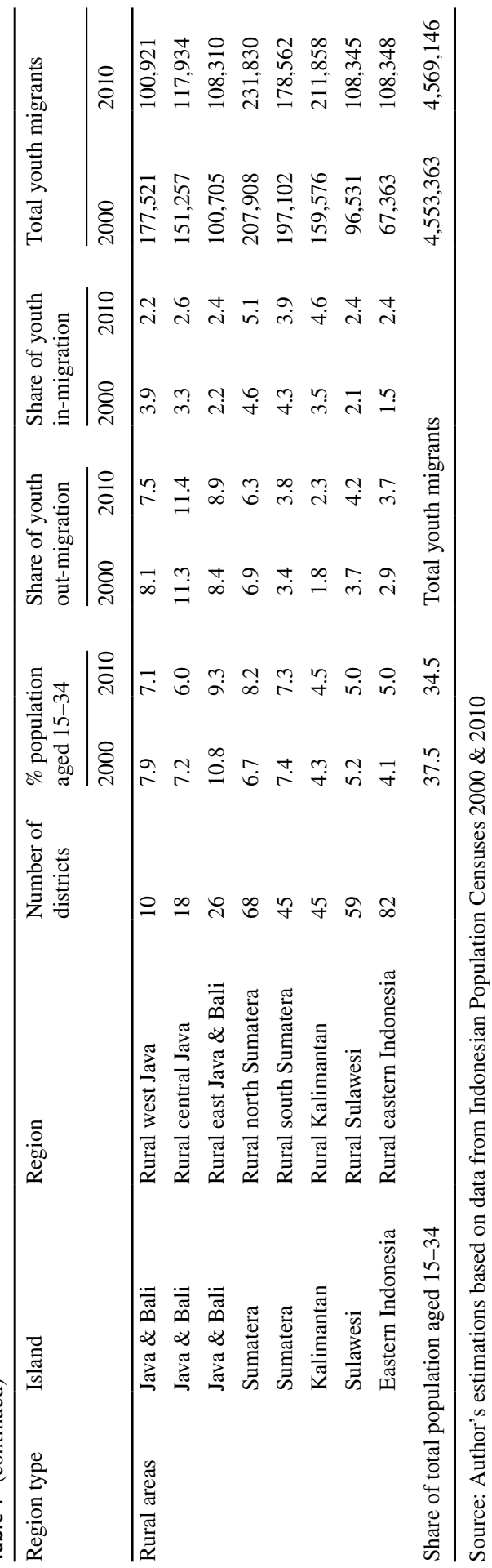


islands had an increasing share of youth migrants, for example, urban and rural areas beyond Java, Bali and Sumatera islands.

Educational backgrounds are divided into three groups: (i) primary education, which refers to those whose highest educational attainment is junior high school or below (includes those who graduated from elementary school only and those with no education); (ii) secondary education, which represents those who completed senior high school; and (iii) tertiary education, which covers young adults who earned a diploma, undergraduate or postgraduate qualification. Information on respondents' education in the datasets only allows us to understand their education background at the time of the censuses. It is important to note the possibility of imprecise deductions about the link between education and migration structure since there is no information on the time frame of the education trajectories. The analysis in this study assumed that migrants earned their highest educational attainment before migrating.

\section{Method}

In analysing the spatial structure of migration, this study applied the multiplicative component methodology (Raymer \& Rogers, 2007; Raymer et al., 2006; Rogers et al., 2002). The multiplicative component model disaggregates migration flows into four components, namely, (i) level of migration (overall component); (ii) relative push factors from each region (origin component); (iii) relative pull factors to each region (destination component); and (iv) other factors affecting migration that are not explained by the push and pull factors, such as physical or social distance (interaction component). Using the multiplicative component method, the analysis points out the relative push and pull factors of each region as well as the spatial connectedness between each pair of regions within the migration system (Rogers et al., 2002). This method provides a conceptually straightforward tool to study the spatial structure of migration.

For each education level, the disaggregation of migration flows in multiplicative form is as follows:

$$
\mathrm{n}_{\mathrm{ij}}(\mathrm{x})=\mathrm{T}(\mathrm{x}) * \mathrm{O}_{\mathrm{i}}(\mathrm{x}) * \mathrm{D}_{\mathrm{j}}(\mathrm{x}) * \mathrm{OD}_{\mathrm{ij}}(\mathrm{x})
$$

where,

$\mathrm{n}_{\mathrm{ij}}(\mathrm{x}) \quad$ an observed flow of migration from region $\mathrm{i}$ to region $\mathrm{j}$ for education level $\mathrm{x}$ $\mathrm{T}(\mathrm{x}) \quad$ overall component (the total number of youth migrants for education level $\mathrm{x}$ )

$\mathrm{O}_{\mathrm{i}}(\mathrm{x}) \quad$ origin component (the proportion of youth migrants leaving region $\mathrm{i}$ for education level $\mathrm{x}$ )

$\mathrm{D}_{\mathrm{j}}(\mathrm{x}) \quad$ destination component (the proportion of youth migrants moving to region $\mathrm{j}$ for education level $\mathrm{x}$ )

$\mathrm{OD}_{\mathrm{ij}}(\mathrm{x})$ interaction component between origin $\mathrm{i}$ and destination $\mathrm{j}$ for education level $\mathrm{x}$ 
The origin-destination flows of youth migration $-\mathrm{O}_{\mathrm{i}}(\mathrm{x})$ and $\mathrm{D}_{\mathrm{j}}(\mathrm{x})-$ corresponding to primary, secondary and tertiary education levels in 2000 and 2010 are visualised in circular plots. The application of circular plots to illustrate migration flows was first introduced by Abel and Sanders (2014). These plots allow us to observe the directional migration flows and identify prominent spatial patterns. The outer sectors of the circular graph represent the regions, whereas the chords connecting them indicate the migration flows. The size of the chords is scaled to the volume of migration flow in thousands. The direction of the spatial movements is illustrated by arrows pointing towards the region of destination.

This study focused on analysing the spatial structure of migration regarding three components, namely, origin, destination and interaction components, and examining these three components by education level. A subsequent analysis was also included to explore how demographic, geographical, socio-economic and cultural factors are related to education-specific youth migration flows in Indonesia. The estimation of factors associated with origin, destination and interaction components was performed by running ordinary least squares (OLS) regression models. Assuming that migrants moved five years prior to the census year, all predictors in the models were lagged by five years. The lagged explanatory variables for the analysis were estimated by applying geometric interpolation and extrapolation from the data in the 2000 and 2010 censuses.

For predicting factors associated with the education-specific origin and destination components of young adult migration in Indonesia, the following models were specified:

$$
\begin{aligned}
& \operatorname{lnO}_{\mathrm{i}}=\beta_{0}+\beta_{1}(\mathrm{EDU})+\beta_{2}\left(\mathrm{EDU} * \mathrm{POP}_{\mathrm{i}}\right)+\beta_{3}\left(\mathrm{EDU} * \mathrm{ODR}_{\mathrm{i}}\right)+\beta_{4}\left(\mathrm{EDU} * \mathrm{TERT}_{\mathrm{i}}\right)+ \\
& \beta_{5}\left(\mathrm{EDU} * \mathrm{NAG}_{\mathrm{i}}\right)+\beta_{6}\left(\mathrm{EDU} * \mathrm{EFI}_{\mathrm{i}}\right) \\
& \operatorname{lnD}_{\mathrm{j}}=\beta_{0}+\beta_{1}(\mathrm{EDU})+\beta_{2}\left(\mathrm{EDU} * \mathrm{POP}_{\mathrm{j}}\right)+\beta_{3}\left(\mathrm{EDU} * \mathrm{ODR}_{\mathrm{j}}\right)+\beta_{4}\left(\mathrm{EDU} * \mathrm{TERT}_{\mathrm{j}}\right)+ \\
& \beta_{5}(\mathrm{EDU} * \mathrm{NAGj})+\beta_{6}\left(\mathrm{EDU} * \mathrm{EFI}_{\mathrm{j}}\right)
\end{aligned}
$$

where,

$\mathrm{O}_{\mathrm{i}} \quad$ origin component from region $\mathrm{i}$

$\mathrm{D}_{\mathrm{j}} \quad$ destination component to region $\mathrm{j}$

EDU education level

POP population size (in thousands, natural logarithm),

ODR old dependency ratio (ODR).

TERT proportion of tertiary-educated population.

NAG proportion of non-agricultural workers.

EFI aggregated ethnic fractionalised index.

Regions with a large population size were expected to send and receive a large number of migrants (Raymer et al., 2011). In addition, regions with low old-age dependency ratios were expected to have a higher number of out-migrants. The proportion of tertiary-educated people represents the regions' human development level (Venhorst et al., 2010), whereas the proportions of non-agricultural workers 
indicate economic development in a region. Regions with a higher development level were assumed to attract more migrants as well as to have more mobile populations. Finally, the ethnic fractionalised index was used to capture cultural heterogeneity in a region, with a higher index representing more ethnic heterogeneity. It is argued that internal migration is not free of cultural motivations because regions that offer cultural amenities through their population's ethnic heterogeneity are likely to attract more migrants, particularly those who are educated (Crescenzi et al., 2017). This study followed Arifin et al.'s (2015) method in quantifying ethnic diversity in Indonesia. ${ }^{1}$

For the estimation of factors contributing to the interaction component, the model was specified as:

$$
\begin{gathered}
\operatorname{lnOD}_{\mathrm{ij}}=\beta_{0}+\beta_{1}(\mathrm{EDU})+\beta_{2}\left(\mathrm{EDU} * \mathrm{CONT}_{\mathrm{ij}}\right)+\beta_{3}\left(\mathrm{EDU} * \mathrm{CONN}_{\mathrm{ij}}\right)+\beta_{4}\left(\mathrm{EDU} * \mathrm{LT}_{\mathrm{ij}}\right)+ \\
\beta_{5}\left(\mathrm{EDU} * \mathrm{EMP}_{\mathrm{ij}}\right)+\beta_{6}\left(\mathrm{EDU} * \mathrm{NAG}_{\mathrm{ij}}\right)
\end{gathered}
$$

where,

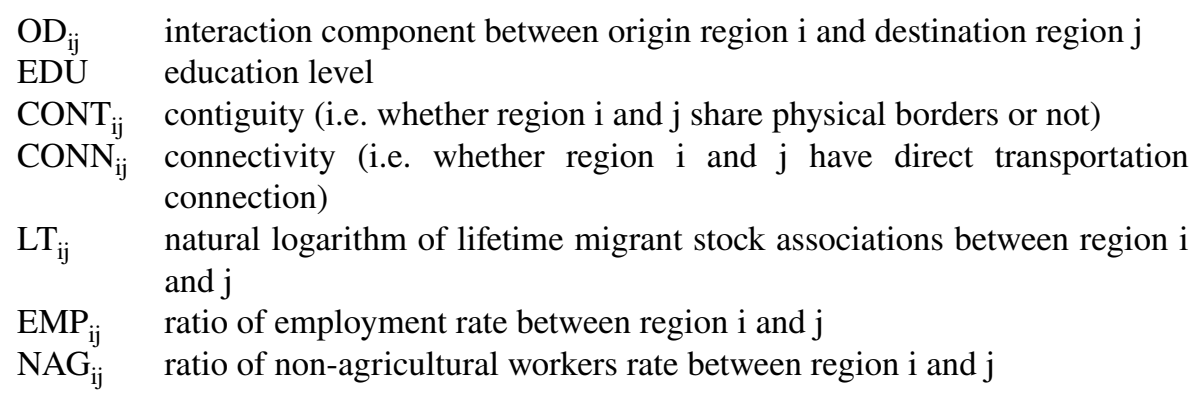

Regional contiguity and connectivity are indicators to represent physical distance and transportation networks across regions. Factors beyond physical distance are also argued to have effects on migration interaction between regions, such as social networks and relative economic factors between regions (Raymer et al., 2011). Lifetime migration stock associations were used to show social networks and cultural ties between regions. It is argued that social networks and cultural ties have prominent roles in facilitating migration (Ryan, 2011). Ratios of employment rate between origin and destination regions illustrate the relative employment opportunities between regions. Economic development associations between origin and destination areas were represented by ratios of non-agricultural workers' rate.

\footnotetext{
${ }^{1}$ Indonesia is one of the most ethnically diverse nations in the world; 1,331 ethnic categories were recorded in its 2010 census (Ananta et al. 2015). Population in-migration can have impacts on the increasing ethnic heterogeneity in destination areas and greater interactions among people with different ethnic backgrounds. In calculating the ethnic diversity in Indonesia, Ananta et al. (2015) reclassified the ethnic categories into more than 600 groups. However, this classification applies only to 2010 census data. Since this study used both 2000 and 2010 census data, the initial classification by Statistics Indonesia (2011a, 2011b) that aggregated ethnic categories in Indonesia into 31 groups is preferred for the ethnic categorisation.
} 


\section{Origin-Destination Flows of Youth Migration in Indonesia}

The origin-destination flows of youth migration corresponding to primary, secondary and tertiary education levels in 2000 and 2010 are visualised in Figs. 3, 4 and 5, respectively. The graphs highlight the top three sending and receiving regions in each education group. The blue chords indicate regions with the largest in-migration flow, and the red chords represent those with the largest out-migration flow. For Figs. 4 and 5, there is an addition of yellow chords, which signify regions with a high number of both in-migrants and out-migrants.

Migration flows by those with the lowest education level (Fig. 3) show that rural regions in Java Island accounted for the majority of out-migration flows in 2000 and 2010. Out-migration from rural central Java shows more dispersed patterns of destination regions. In contrast, out-migration from rural west Java were mainly directed to Jakarta and Outer Jakarta. Rural east Java sent mainly primary-educated migrants towards its metropolitan counterpart (Surabaya). Moreover, Jakarta and Outer Jakarta also show their dominance as destination regions for migration by the lowest education level. These two regions attracted mainly in-migrants from rural areas in Java, but it is also noticeable that they gained primary-educated migrants from other urban and metropolitan regions. Primaryeducated level migration can imply a situation of higher opportunity costs of higher education in areas of origin. This situation can encourage school discontinuation, which is followed by labour market entry in other areas. Migration by this group is seen as a response to labour market demands in destination areas that do not entail high skills. For example, the rapid growth of informal sectors,

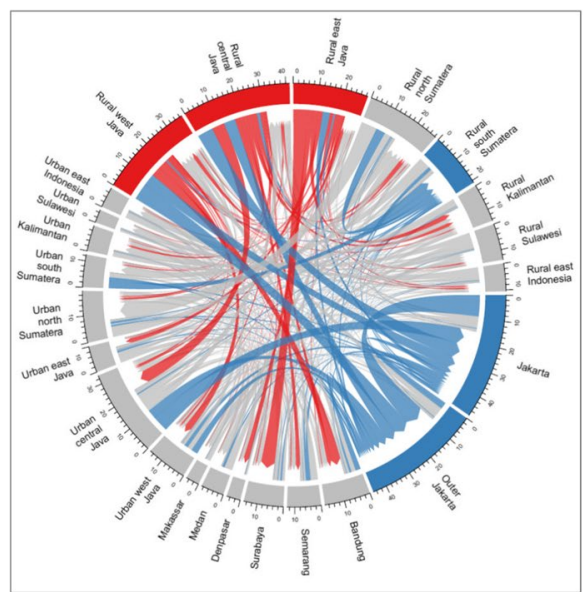

Region with highest number of out-migration flows

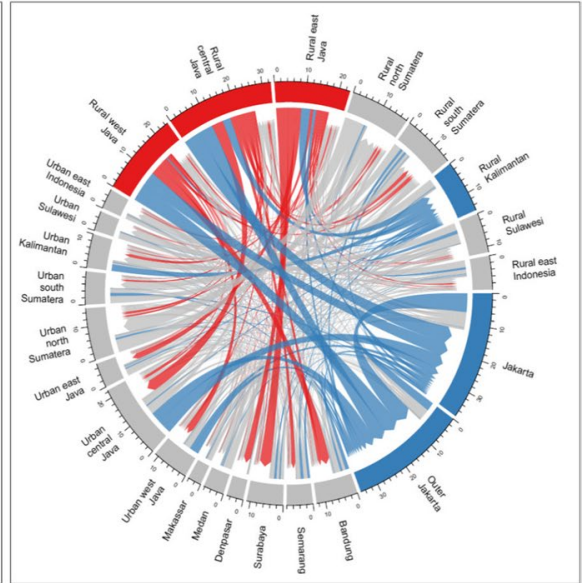

Region with highest number of in-migration flows

Fig. 3 Origin-destination primary-educated migration flow, 2000 (left) and 2010 (right) (in thousands). Source: Authors' calculations 

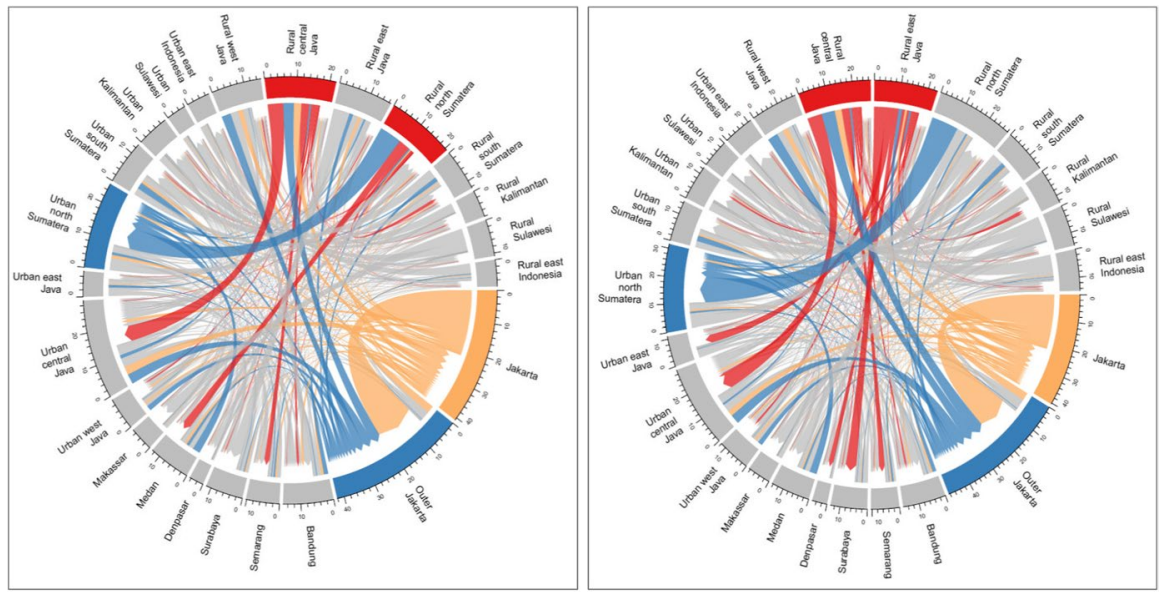

Region with highest number of in- \& out-migration flows

Region with highest number of out-migration flows

Region with highest number of in-migration flows

Fig. 4 Origin-destination secondary-educated migration flow, 2000 (left) and 2010 (right) (in thousands). Source: Author's calculations
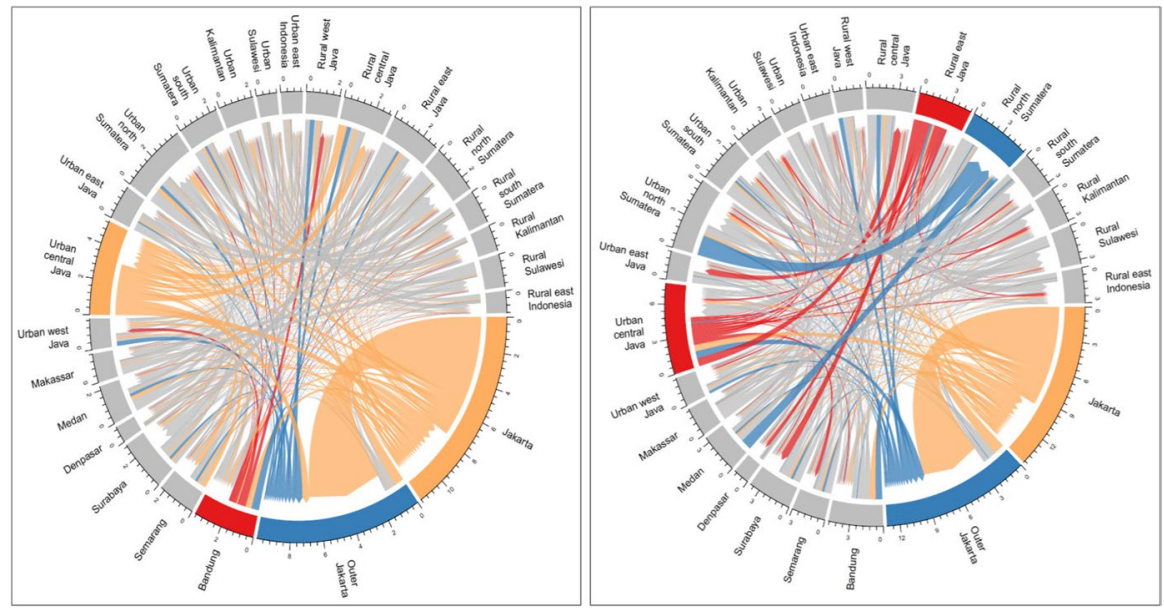

Region with highest number of in- \& out-migration flows

Region with highest number of out-migration flows

Region with highest number of in-migration flows

Fig. 5 Origin-destination tertiary-educated migration flow, 2000 (left) and 2010 (right) (in thousands). Source: Author's calculations

alongside the expansion of economic activities, in Jakarta and Outer Jakarta can explain the high in-migration flows of low-educated migrants (Jones et al., 2016).

The migration patterns of the secondary-educated population (Fig. 4) show that rural regions are no longer the only prominent source of young out-migrants. Jakarta sent a considerable proportion of secondary-educated migrants. At the 
same time, this region also attracted a high share of in-migrants with secondary level qualifications. The graphs show that Jakarta sent its young secondaryeducated population mainly to its surrounding region (Outer Jakarta). However, no region shows dominance as a source of in-migration flows towards Jakarta. A similar situation was found in the in-migration pattern towards Outer Jakarta. Besides a great proportion of inflows from Jakarta, the rest of the in-migrants originated from various regions. A great number of manufacturing factories, as well as rapid development in service sector industries such as retail and hospitality services, may explain the high level of in-migration towards both regions. This is because early entry as a labourer in such work fields usually requires only a senior high school qualification.

Figure 5 shows the origin-destination patterns of tertiary-educated migration. Since tertiary education systems are mainly concentrated in metropolitan and urban areas, these regions became the prominent source for tertiary-educated migration, except for rural east Java in 2010. It is interesting to note that Jakarta in both censuses and urban central Java in 2000 simultaneously attracted and lost a remarkable proportion of highly educated migrants. The three top sending regions of tertiaryeducated migrants in both censuses, namely, Jakarta, Bandung and urban central Java, are home to a great number of reputable universities, which highlights the crucial role of these regions for human capital formation in the country. However, they suffered from net outflows of highly skilled migrants due to the low retention of tertiary graduates. While Jakarta sent tertiary-education migrants mainly to the outer part of this region, urban central Java and Bandung lost their tertiary-educated population to various regions. The remarkable tertiary-education out-migration from Jakarta to the surrounding cities can be attributed to the rapid development of housing states in Outer Jakarta (Jones et al., 2016).

In contrast, the increasing importance of rural areas as destination areas of tertiary-educated migrants was evident in 2010. This may indicate the existence of less centralised knowledge-based industries across regions in the country over the years. Not only did rural north Sumatera become one of the top destinations in 2010, but also nearly a quarter of migrants with a tertiary degree moved towards rural regions outside Java Island between 2005 and 2010, an increase from a $13 \%$ in-migration rate in 2000 . This situation may have been due to the regional decentralisation policy initiated in 1999, followed by the proliferation of many new districts across the country. The establishment of new administrative regions offered wide working opportunities in local civil services (World Bank, 2003) that commonly required tertiary education qualifications. In recent years, Indonesian governments have also launched higher incentives for certain skilled workers, such as teachers, in less developed regions (World Bank, 2006). This policy encourages urban-rural migration by tertiary-educated groups, particularly new graduates. As suggested by Corcoran et al. (2010), some tertiary graduates are willing to take job opportunities in peripheral or remote areas for their early career entry.

Overall, persistent patterns of origin-destination flow can be found within the youth migration's spatial structure in Indonesia over the 10 years. Rural regions acted as prominent sources for primary- and secondary-educated migration, while 
metropolitan and urban areas sent the highest share of tertiary-educated migrants. Moreover, Greater Jakarta-which covers Jakarta and its surrounding citiesbecame the main destination for young migrants at any educational level.

\section{Origin-Destination Interaction within Youth Migration Structure}

Origin-destination flows show the prominent role of regions with a bigger population size in the interregional migration structure. The interaction components from the multiplicative component model, on the other hand, illustrate the relative level of connections occurring between regions by controlling for the overall levels of migration from the origin regions and to the destination regions.

The interaction components for education-specific migration flows in 2000 and 2010 are set out in Appendix Tables 4, 5, 6, 7, 8, and 9. Following Raymer et al. (2006), one of the examples for the ratio interpretation from origin, destination and interaction components of the primary-educated migration in 2000 (Appendix Table 4) is as follows:

$$
\begin{aligned}
& \mathrm{n}_{(\text {Jakarta,OuterJakarta) }}(\mathrm{p})=\mathrm{T}(\mathrm{p}) * \mathrm{O}_{\text {Jakarta }}(\mathrm{p}) * \mathrm{D}_{\text {OuterJakarta }}(\mathrm{p}) * \mathrm{OD}_{\text {Jakarta,OuterJakarta }}(\mathrm{p}) \\
& =(2,334,329) *(0.067) *(0.156) *(3.761) \\
& =92,256
\end{aligned}
$$

In other words, among 2,334,329 primary-educated young migrants in Indonesia in 2000, 6.7\% moved from Jakarta and $15.6 \%$ moved to the surrounding cities of Jakarta. The interaction component of 3.761 implies that there were about 37 observed young migrants for every 10 expected migrants from Jakarta to the outer part of this region. The interaction ratio of one or above indicates a strong association between these two places, while any ratio below one illustrates a weak association between a pair of origin and destination regions. As indicated in the appendices, the interaction ratios show a very strong association between regions within the same island. This situation illustrates a tendency for short-distance migration among young adults in Indonesia at any education level.

The following discussion emphasises the interaction components of several prominent regions in education-specific origin-destination flows, namely, in-migration towards Jakarta and Outer Jakarta, in-migration and out-migration in urban central Java, and in-migration towards rural east Indonesia.

Jakarta's importance in attracting young migrants is amplified by examining the spatial interaction values within Java Island. Figure 6 shows that Jakarta consistently had strong interactions with other metropolitan cities in Java for tertiary-educated migration. This situation illustrates the tendency of spatial movements within a similar development level of origin and destination areas for highly educated migrants. Working opportunities may not be the only factors influencing the decision for migration within metropolitan areas. The similarity of lifestyle amenities can also be a major consideration for this type of migration. Interactions between Jakarta and rural and urban areas are particularly strong at the primary and secondary education levels. However, the strong associations are shown only for regions in west and 


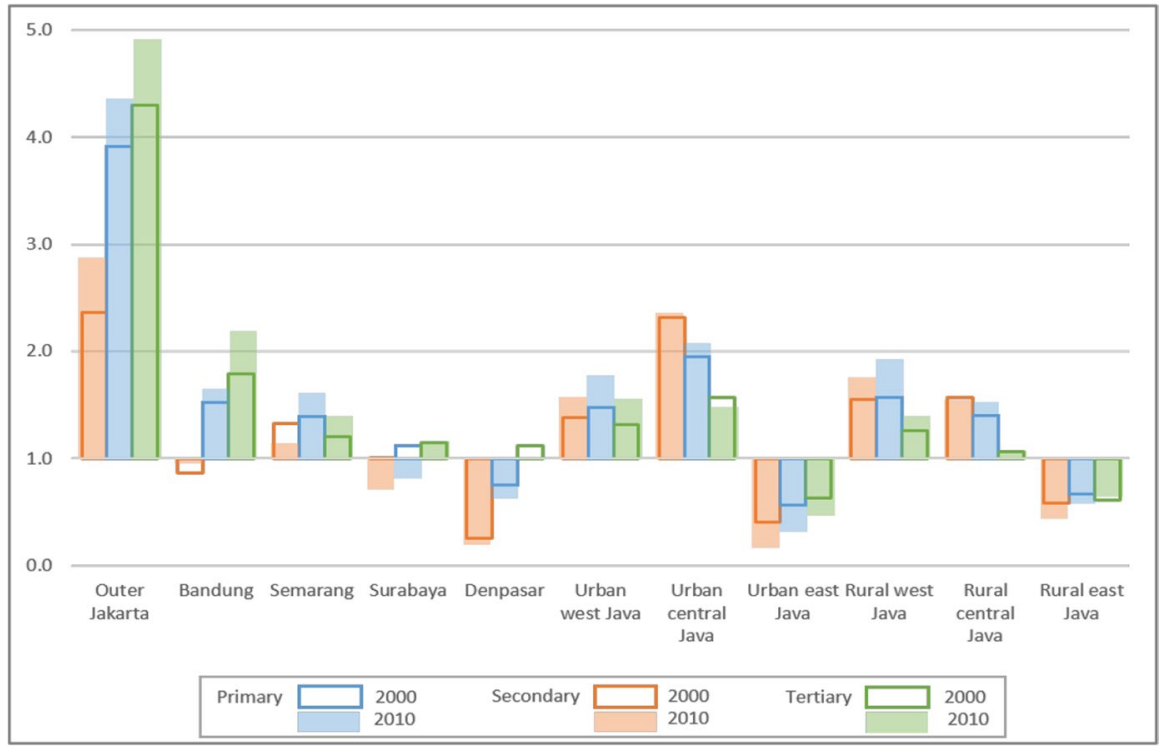

Fig. 6 Interaction components of migration by education level within Java Island towards Jakarta. Source: Author's calculations

central Java, while the patterns of weak associations towards Jakarta are exhibited in the interaction ratio of urban and rural areas in east Java. Since Jakarta is situated in the westernmost part of the island, the regions in east Java have the least spatial connectedness with the region. This situation emphasises how geographical proximity matters for the spatial interaction among regions.

Another prominent destination region in the education-specific migration flows in Indonesia is Outer Jakarta. Figure 7 displays the interaction components of migration within Java towards the Outer Jakarta region. While Jakarta shows strong interactions with all other metropolitan areas within the island, Outer Jakarta had strong interaction only with Jakarta and Bandung, the two metropolitan cities with the least spatial distance to this region. In addition, the interactions for tertiary-educated migration were generally weaker than interaction for the other two education levels.

Urban central Java was consistently one of the top sending regions for tertiaryeducated migration. The origin components illustrate that nearly $9 \%$ of tertiaryeducated migrants came from this region in both censuses (Appendx tables 8 and 9). In addition, urban central Java simultaneously gained a noticeable portion of secondary-educated migrants (Appendix Tables 6 and 7). Since tertiary-educated migrants may include previous secondary-educated migrants who remigrated after finishing their study, migration interactions linked to this region can also be related to the structure of tertiary student migration. Although Malamassam (2016) found that only $23 \%$ of migrants aged 15 to 24 in Indonesia moved for education-related motives, this type of migration has a remarkable impact on the age profile of migration at the regional level (Wilson, 2015). 


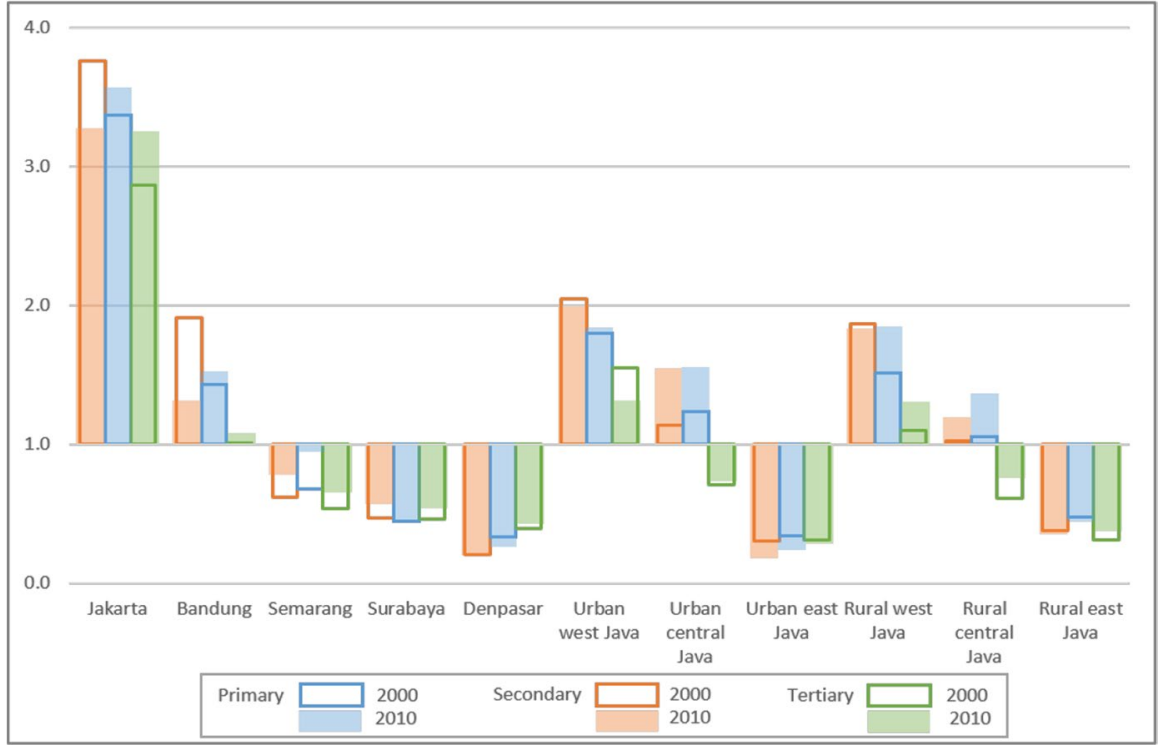

Fig. 7 Interaction components of migration by education level within Java Island towards Outer Jakarta. Source: Author's calculations

While metropolitan and rural counterparts of urban central Java show remarkable interactions within the secondary education in-migration patterns, this region also had strong associations with several regions beyond Java, such as urban south Sumatera, urban Kalimantan and urban east Indonesia (Fig. 8). The strong interactions can be attributed to several factors, such as regional connectivity through

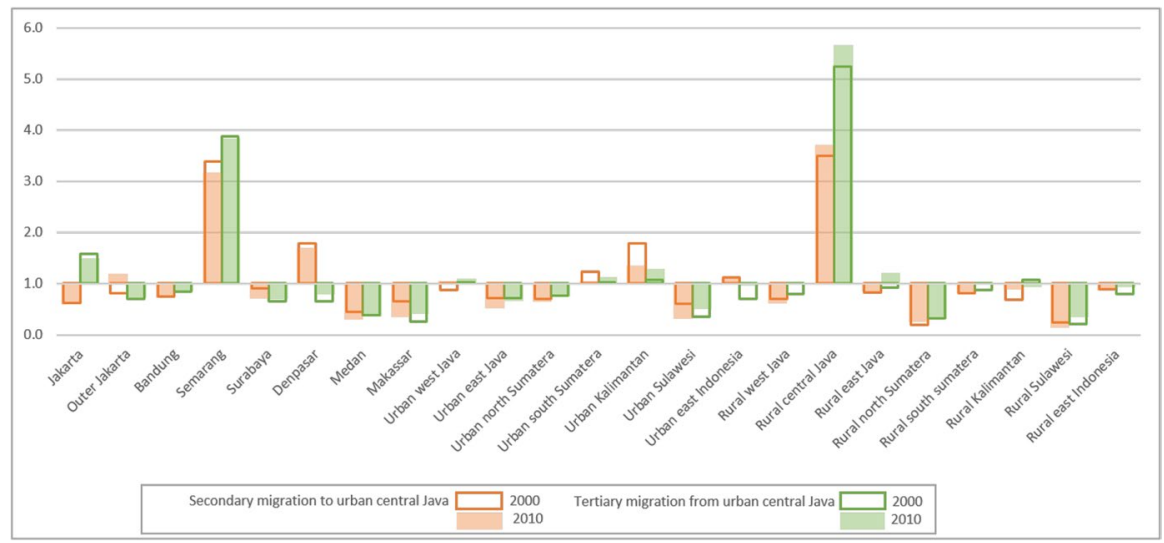

Fig. 8 Interaction components of secondary-educated migration to urban central Java and tertiary-educated migration from urban central Java. Source: Author's calculations 


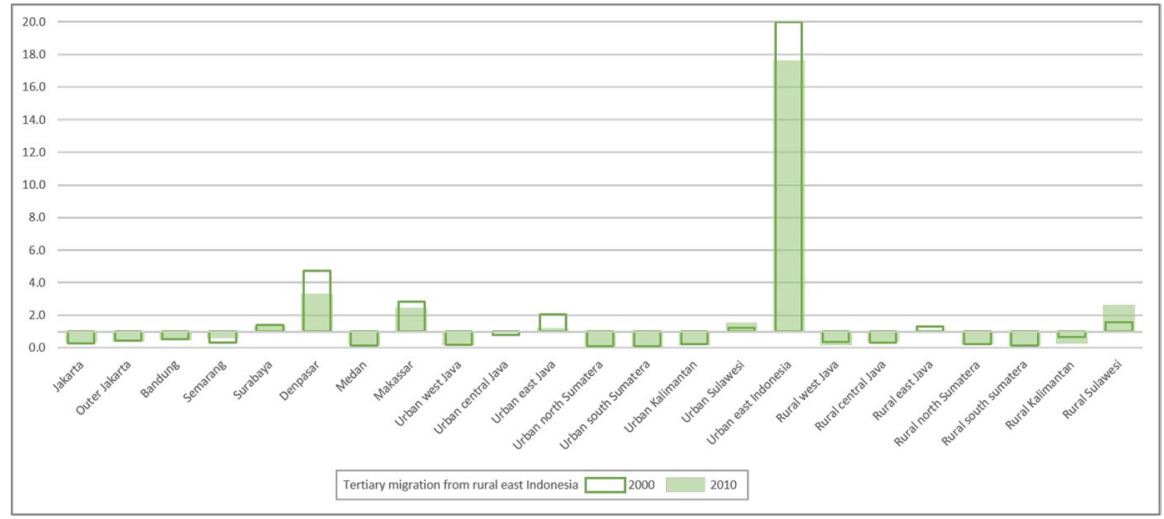

Fig. 9 Interaction components of tertiary-educated migration towards rural east Indonesia. Source: Author's calculations

the ease of transportation between these urban areas, as well as the relative education and employment opportunities between the pair of origin and destination regions. Moreover, the interaction components of tertiary-educated out-migration from urban central Java show that this region's strong interactions were not limited to regions outside Java. The dispersed patterns of the origin-destination pairs can illustrate more diffuse economic opportunities for skilled workers. In addition, the interactions between urban central Java and other rural areas show increasing ratios over the years. While the pattern of urban-rural migration is more common in late adult or elderly migration, this flow is increasingly found in young adult migration (Stockdale \& Catney, 2014), particularly amongst highly educated people with specific skills (Corcoran, et al., 2010; Martel et al., 2013). The pattern of urban-rural migration represents the critical impact of this spatial transition on the deconcentration of the highly educated population and restructuring of rural economies (Lomax et al., 2014).

The destination component for tertiary-educated migration towards rural east Indonesia markedly increased from 1.8\% in 2000 to 4\% in 2010 (Appendix Tables 8 and 9). Since rural east Indonesia is generally considered the least developed region in the country, this situation may illustrate the improved attraction towards this region over time. Figure 9 shows a tendency of weaker interactions of tertiary-educated migration towards this region between 2000 and 2010, particularly with some nearby regions, such as Denpasar, Makassar, urban and rural east Java, and urban east Indonesia. However, the interactions with regions in the western part of Indonesia show slightly increased ratios. The improvement of regional connectivity between the western and eastern parts of the country may have affected this situation. In addition, the better knowledge-based working opportunities between more developed regions and rural areas may have also been an influential factor in the increasing interaction ratios. Since rural areas are highly linked to less human 
development levels, knowledge-based opportunities in such areas are considered less competitive than migrants' origin areas. Thus, in-migration towards rural areas can be seen as a means to gain occupational mobility (Malamassam et al., 2018).

\section{Factors Contributing to Migration Components}

Further analysis was conducted to explain underlying factors of youth migration's spatial structure in Indonesia. Table 2 presents the determinants of origin (Model 1) and destination (Model 2) components.

Table 2 OLS regression results for origin \& destination component

\begin{tabular}{|c|c|c|c|c|}
\hline \multirow[t]{2}{*}{ Variables } & \multicolumn{2}{|c|}{ Model 1 (origin component) } & \multicolumn{2}{|c|}{ Model 2 (destination component) } \\
\hline & 2000 & 2010 & 2000 & 2010 \\
\hline & Coef & Coef & Coef & Coef \\
\hline Constant & $-13.136^{* * *}$ & $-14.195^{* * *}$ & $-11.065^{* * *}$ & $-10.922 * * *$ \\
\hline \multicolumn{5}{|l|}{ Education } \\
\hline - Primary (reference) & - & - & - & - \\
\hline - Secondary & 0.864 & 1.098 & 1.273 & 2.496 \\
\hline - Tertiary & 0.594 & 0.872 & 1.109 & 1.161 \\
\hline \multicolumn{5}{|c|}{ Interaction with population size } \\
\hline - Primary & $0.944 * * *$ & $0.969 * * *$ & $0.881 * * *$ & $0.872 * * *$ \\
\hline - Secondary & $0.878 * * *$ & $0.922 * * *$ & $0.700 * * *$ & $0.593 * * *$ \\
\hline - Tertiary & $0.878 * * *$ & $0.857 * * *$ & $0.755^{* * *}$ & $0.796 * * *$ \\
\hline \multicolumn{5}{|c|}{ Interaction with old dependency ratio } \\
\hline - Primary & 0.102 & 0.144 & $-0.197 * *$ & $-0.153 *$ \\
\hline - Secondary & 0.060 & 0.109 & $-0.244 * *$ & $-0.195 * *$ \\
\hline - Tertiary & 0.006 & 0.079 & $-0.219 * *$ & $-0.178^{*}$ \\
\hline \multicolumn{5}{|c|}{ Interaction with proportion of educated population } \\
\hline - Primary & 0.014 & -0.010 & -0.034 & 0.076 \\
\hline - Secondary & 0.086 & 0.075 & -0.024 & 0.061 \\
\hline - Tertiary & $0.255 * * *$ & $0.210 * * *$ & -0.009 & 0.084 \\
\hline \multicolumn{5}{|c|}{ Interaction with proportion of non-agricultural workers } \\
\hline - Primary & 0.010 & 0.013 & $0.021 * *$ & 0.006 \\
\hline - Secondary & 0.004 & -0.002 & $0.031 * * *$ & $0.015^{*}$ \\
\hline - Tertiary & 0.010 & 0.006 & $0.023 * * *$ & 0.002 \\
\hline \multicolumn{5}{|c|}{ Interaction with ethnic fractionalisation } \\
\hline - Primary & 0.443 & 0.962 & -0.293 & -0.195 \\
\hline - Secondary & 0.865 & 1.369 & -0.840 & -1.007 \\
\hline - Tertiary & -0.530 & 0.114 & -0.672 & -0.496 \\
\hline Adjusted $\mathrm{R}^{2}$ & 0.69 & 0.68 & 0.65 & 0.60 \\
\hline
\end{tabular}

Number of observations $=72$

$*, * *, * * *$ indicates significance at the $90 \%, 95 \%$, and $99 \%$ level, respectively

Source: Author's calculations 
Results from Model 1 indicate that population size is a significant predictor in explaining regional attraction at any education level over the years. This finding confirms the patterns from the circular plots that show regions with the highest out-migration flows were centralised in Java, the most populous island in the country. Further, the population's age structure in origin areas is not significantly associated with outflows of young people.

The proportion of the tertiary-educated population in origin areas consistently shows a significant influence on the outflows of tertiary-educated migrants in both censuses. Thus, the results indicate a stronger likelihood of human capital flows from regions with a higher human development level. Moreover, the proportion of non-agricultural workers in origin areas has no significant association with the origin component at any level of education. Thus, the level of regional development in origin areas appears to have less significance in explaining youth out-migration flows.

Most of the areas within Java, except for Jakarta, are considered culturally homogeneous because of the dominance of Javanese and Sundanese ethnicities in their population. Meanwhile, regions beyond Java are more heterogeneous. The cultural heterogeneity in the origin area may reflect the migration culture by its population. Thus, it was expected that regions with high ethnic fractionalisation would have high migration rates. However, this determinant was insignificant as a push factor of youth migration in both censuses.

The results from Model 2 show significant effects of population size in attracting young migrants over the years at any level of education. Again, these results confirm the expectation that more populated regions would attract a higher number of migrants. The old dependency ratio is also shown to have significantly affected young in-migrant flows at any level of education in both censuses. Indonesia's age structure shows a decreasing trend of dependency ratio during 2000 and 2010 (Statistics Indonesia, 2011a, 2011b). However, the ratios were still highly varied across regions. The negative direction of the association indicates that regions with a higher share of the young population were likely to attract more young migrants.

The proportion of tertiary-educated individuals representing the human development level of a region is argued to be an attraction force for youth in-migration, particularly for those who are educated (Faggian et al., 2014). However, the results from the regression shows that the effect of this predictor on young in-migrants flows was not significant. The proportion of non-agricultural workers is also described as a major migration attraction since it represents the industrialisation and urbanisation in a region. This variable was significant for most education-specific in-migration flows, except for primary- and tertiary-educated migration in 2010. Thus, agriculturally dominant regions are less likely to gain in-migrants, particularly those who are least educated and those who are highly educated. Finally, while it is argued that regions with a multicultural background have stronger pull factors for in-migrants (Crescenzi et al., 2017), ethnic fractionalisation had an insignificant effect on the youth in-migration flows at any education level over the years.

Model 3 was run to understand contributing factors to the interaction components. The OLS regression results are summarised in Table 3. Here, both predictors related to the regions' physical connectedness; that is, contiguity and connectivity had significant effects on the spatial interactions for all levels of education over both 
Table 3 OLS regression results for the interaction component

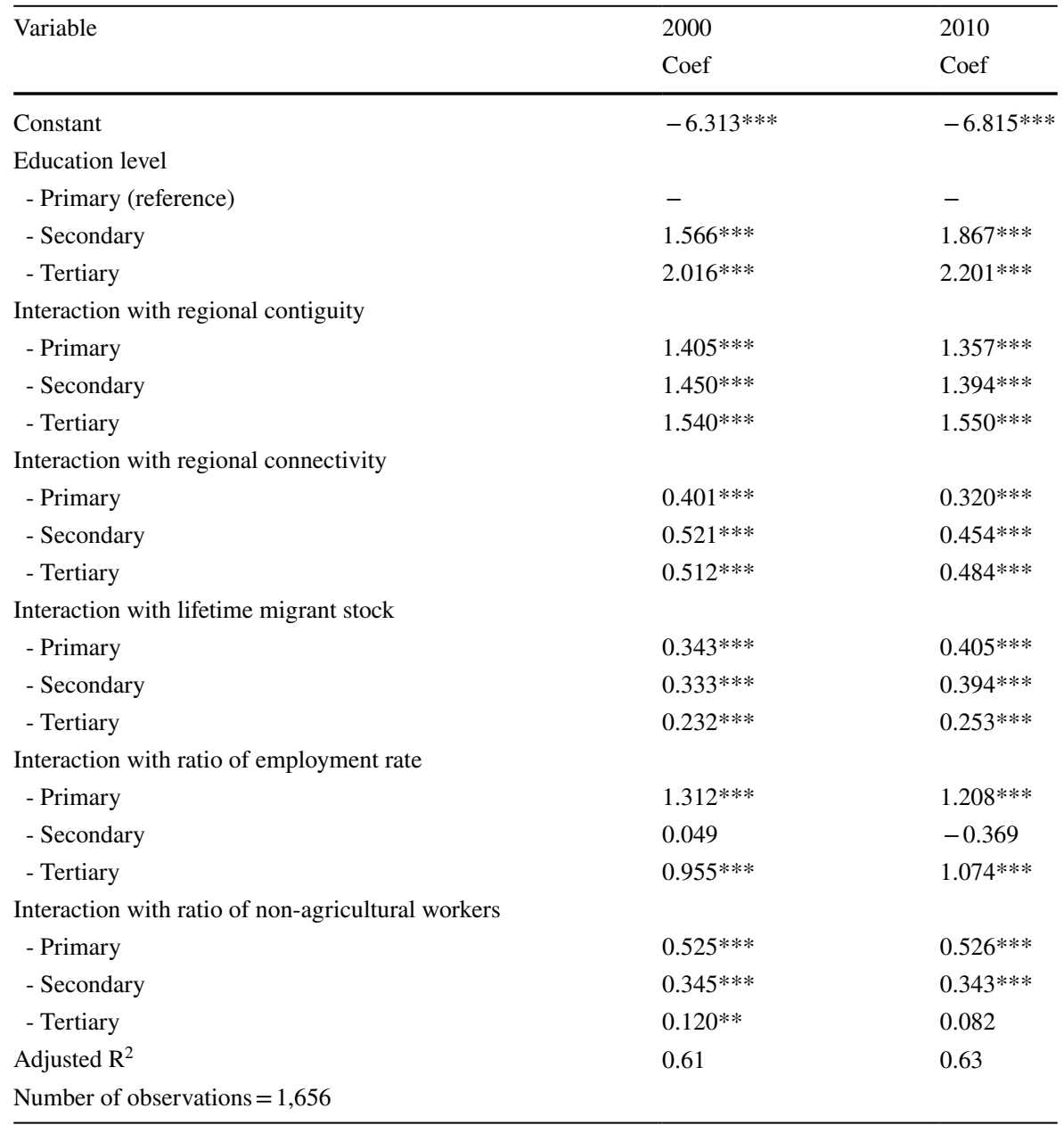

$*, * *, * * *$ indicates significance at the $90 \%, 95 \%$, and $99 \%$ level, respectively

Source: Author's calculations

periods. Migrants tended to move to nearby regions, and this pattern was found to be more pronounced as education levels increased. While highly educated migrants are argued to be more likely to make long-distance movements (Rosenbloom \& Sundstrom, 2004; Spring et al., 2016), the present study suggests that tertiary-educated migrants are likely to move to nearby regions. As shown in the case of a great number of tertiary-educated migrants from Jakarta to its surrounding regions, migration by this particular group can be viewed as a strategy to maximise their return to education by simultaneously accessing affordable housing in the peripheral areas and commuting to work in the capital city (Jones et al., 2016). 
Lifetime migrant stock association between origin and destination areas indicate social networks and cultural ties. The effect of lifetime migrant stock was statistically significant across the three education groups. However, the effect seems to be more pronounced in the group with lower levels of education. The key roles of communities of origin in destination regions can mainly be observed when migrants face obstacles during their migration processes, such as financial, living arrangement or community integration problems (Ryan, 2011). For low-educated migrants, in particular, the presence of social networks and cultural ties might work as a complement to the limited human capital they have.

The ratio of employment rate had a positive effect on the interaction components of primary- and tertiary-educated migration. Interestingly, it had no significant effect on origin-destination interaction within the secondary-educated migration structure. For the lowest and highest education levels, the destination regions were more likely to provide wider employment opportunities than their origin regions. However, for secondary-educated migration, the insignificance of this predictor can be partially attributed to the variations of migration motive by this group. Economic- and family-related motives have been the main motives of youth migration in Indonesia (Malamassam, 2016), but educationrelated motives were found to be a prominent feature in youth migration towards regions that provide access to elite higher education institutions. Such regions may have lower employment rates than migrants' region of origin because of their higher share of unemployed students. Further, the ratio of non-agricultural workers showed significant effects on primary- and secondary-educated migration in both censuses. This situation can give an overview of the migration structure at the lower education level, which entails less urbanised origin areas and more industrialised destination regions. The insignificant effect of this variable on the interaction component of tertiary-educated migration in 2010 illustrates that the spatial interactions of tertiary-educated migration in recent years were likely to occur between regions with a similar development level. These results indicate the likelihood of migrants within a similar regional type being more highly educated than those who move across different regional types (Rebhun \& Brown, 2015).

\section{Conclusion}

This paper investigated the spatial structure of youth migration in Indonesia by education level and explored factors contributing to the education-specific migration structure. While previous studies on migration patterns have focused mainly on the push and pull factors of each region, this study provides a more comprehensive discussion on the spatial structure of youth migration. The spatial structure of migration is defined as a decomposition of migration into relative push and pull factors of each region and level of spatial interactions between places. Spatial structures of youth migration have varied among different educational backgrounds. Rural regions have acted as prominent sources for 
primary- and secondary-educated migration, while tertiary-educated migrants have originated mainly from metropolitan and urban areas. Moreover, Jakarta and its surrounding cities have become the main destination regions for young migrants. A noticeable pattern exists in the increasing proportion of tertiaryeducated in-migration towards rural regions. In addition, strong origin-destination interactions were found within intra-island migration and nearby regions. For tertiary-educated migration, more dispersed patterns of origin-destination pairs were observed.

It was found that regions with higher populations sent and attracted a higher number of migrants. For the primary-educated migrants, the urbanisation level of origin and destination areas appeared to have a more pronounced effect on the spatial structure of their migration. Regions with better human development levels exhibited higher likelihood of sending tertiary-educated migrants. Moreover, regional connectedness was shown to be stronger on as education levels increased. The reverse occurred with the inclusion of social networks and cultural ties. The relative employment opportunities had mixed effects on the education-specific interaction components. For the lowest and highest education levels, the destination regions were more likely to provide wider employment opportunities than their origins. However, for secondary-educated migration, the opposite patterns were found. Further, the effects of relative urbanised level between regions indicate that primary- and secondary-educated migration flows were more likely to occur between regions with different economic development levels.

Education and employment opportunities in Indonesia across regions have suffered from a wide inequality gap over time. The spatial structures of educationspecific youth migration flows have reinforced this situation in light of the prominent role played by more developed regions as sending and destination regions. However, the increasing importance of rural areas in the tertiary-educated migration structure suggests that knowledge-based sectors play a substantial role in improving human capital accumulation in rural areas. Amid the rapid development of informal sectors alongside the economic growth of big cities and metropolitan areas in Indonesia, economic opportunities appear to have had a more pronounced effect in the migration structure of the least educated group in this study. This situation may affect not only social issues, such as poverty and housing problems, but also the human capital composition in destination regions. Thus, it is important for national and local governments to design social policies that address the implications of education-specific migration flows in human capital redistribution across regions.

Research on migrants' human capital contribution to regional development should also examine migrants' retention in their areas of origin. Since young adults experience multiple spatial movements during their lifetime, further work on the migration dynamics of the young population is highly encouraged. Future studies should be directed at expanding migration datasets used for analysis to improve understanding of young adults' migration processes and their effect on human development in Indonesia. 


\section{Appendix}

Table 4 Multiplicative component matrix of primary-educated migration, 2000

\begin{tabular}{|c|c|c|c|c|c|c|c|c|c|c|c|c|c|c|c|c|c|c|c|c|c|c|c|c|c|}
\hline & 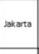 & $\mid \begin{array}{l}\text { Ous } \\
\text { Jescarto }\end{array}$ & Bsnare & Irang & strabsia & Denoser & meson & sessoser & $\begin{array}{l}\text { Untion } \\
\text { west } \\
\text { jove }\end{array}$ & $\begin{array}{c}\text { Urbon } \\
\text { certeral } \\
\text { sore }\end{array}$ & \begin{tabular}{|l|} 
Uitbon \\
eas \\
Jaro \\
\end{tabular} & \begin{tabular}{|} 
Urbon \\
nerth \\
suraterer
\end{tabular} & \begin{tabular}{|c|} 
Urbon \\
somen \\
Sumbereo
\end{tabular} & $\begin{array}{l}\text { Uutbon } \\
\text { immantian }\end{array}$ & $\begin{array}{l}\text { Uitom } \\
\text { sulanes }\end{array}$ & 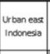 & $\begin{array}{l}\text { Rusal } \\
\text { wes: } \\
\text { fore }\end{array}$ & 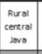 & \begin{tabular}{|l|}
$\begin{array}{c}\text { Rurol } \\
\text { ean } \\
\text { saro }\end{array}$ \\
\end{tabular} & $\begin{array}{c}\text { Rurot } \\
\text { sornt } \\
\text { sumerese }\end{array}$ & \begin{tabular}{|c|} 
Rurat \\
soven \\
sumberere
\end{tabular} & $\begin{array}{l}\text { Rivel } \\
\text { rasimaman }\end{array}$ & $\begin{array}{l}\text { SArat } \\
\text { Suswes }\end{array}$ & $\begin{array}{l}\text { Riscleas } \\
\text { insoness }\end{array}$ & $\begin{array}{l}\text { Origh } \\
\text { comp. }\end{array}$ \\
\hline carto & 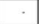 & 3.761 & 0.615 & 0.821 & 0.161 & 0.363 & 102 & 0.154 & 1.070 & 1146 & 0.234 & 0.510 & 0.444 & 0.217 & 0.146 & 0.180 & 1155 & 1688 & 0.424 & 0.471 & 0.328 & 0.176 & 0.121 & 0.204 & 0.067 \\
\hline Outer & 2354 & & 65 & 0.345 & cosst & 0076 & 182 & 0.054 & 2.893 & 0.698 & 0.105 & 0.318 & 0.414 & 121 & 0.052 & 0.791 & 5.45 & 1.354 & 0.351 & 0.354 & 612 & .236 & 1.075 & & 0.038 \\
\hline Eercouns & 0.857 & 1913 & & 0.394 & 0.127 & 0.254 & 0.253 & 0.137 & 2.469 & 0.633 & 0.224 & 0.368 & 0.464 & 1.166 & 0.11 & 0.101 & 5.001 & 1.141 & 0.446 & $0.49:$ & 0.54 & 0.396 & 0.12 & 0.45 & 0.031 \\
\hline Semsare & 1.330 & 0.623 & 0.496 & & 0.546 & 219 & 126 & 0.171 & 0.432 & 4.288 & 0.528 & 0.596 & & & & & 0.475 & 4460 & \begin{tabular}{|l}
1.179 \\
\end{tabular} & 0.449 & & & & & 0.032 \\
\hline Suratova & 2.011 & 0.470 & 0.400 & 1959 & . & 1922 & 0.132 & 0.988 & 0.439 & 0.798 & 6222 & 0.369 & 0.308 & 3.260 & 0.83 & 0.877 & 0.437 & 0.722 & 8.318 & 0.28 & 0.29 & 1.41 & 0.52 & 1.2 & 0.022 \\
\hline Derpases & 0.255 & 0.205 & 189 & 0255 & 0.400 & . & 0.114 & 0.552 & 0.121 & 0.490 & 5.161 & 0.118 & 0.417 & & 0.358 & 716 & 0297 & 0.258 & 11.888 & 0.11 & & & & & $\infty$ \\
\hline Netaran & 0.559 & 0.518 & 991 & 0.162 & 0.061 & 0.063 & & 0.085 & 0.678 & 0.169 & 0.046 & 4006 & 0.920 & 0.12 & 0.05 & 0.057 & 0.230 & 0.183 & 0.07 & 8.85 & 0.85 & 000 & 0.05 & 0.058 & 0.021 \\
\hline Mataserer & 0.240 & 0.021 & 128 & 0.225 & 0.152 & 0.173 & 0.098 & & 0.016 & 0.162 & \begin{tabular}{|l|l|} 
\\
\end{tabular} & 0.25 & 0.174 & & 7.318 & 78 & 0.003 & 0.340 & 0.2 & 0.00 & & & $21 x$ & & 208 \\
\hline tronives & 2.386 & 2005 & 1991 & 0.588 & 0.09 & 0048 & 0.078 & 0.059 & - & 0.477 & 0.150 & 0.376 & 0.431 & 0.106 & 0.012 & 0.035 & 4634 & 0.687 & 0.132 & 0.220 & 0.290 & .318 & 0.081 & & .036 \\
\hline & 2310 & 1.138 & 0.795 & 3.64 & 0.318 & 0.365 & 0.130 & 0.147 & 1.005 & & 0.387 & 0.25 & 0.27 & 277 & 0.11 & 0.139 & 0.694 & 3195 & 1057 & 0.43 & 47) & & 16 & & \\
\hline tore & 0.410 & 0.307 & 0.256 & 0.390 & 6.554 & 6.415 & 0.052 & 0.557 & 0.261 & 0.395 & . & 0.429 & 0.198 & 1.520 & 0.311 & 0.421 & 0.184 & 0.277 & 6469 & 0.410 & 0.574 & 1.444 & 0.900 & 1.505 & 2.031 \\
\hline & 0.648 & 0.442 & 0.540 & 0.295 & 0.058 & 0.111 & 7.941 & 0.459 & 0.345 & 0.354 & 0.117 & & 1.083 & 0.19 & Q & 0.103 & 0.248 & 0.258 & 0.22 & $856:$ & 0970 & & & & 0.03 \\
\hline & 0.875 & 0.678 & 0.583 & 0.909 & 0.062 & 0.100 & o.sis & 0.098 & 0.443 & 0.566 & \begin{tabular}{|l|l|l|} 
\\
0.152
\end{tabular} & 1438 & - & 0.440 & 0.025 & 0.050 & 0.439 & 0.578 & \begin{tabular}{|l|l|} 
\\
\end{tabular} & 1.471 & 8.282 & 0.257 & 0.197 & 0.140 & 0.029 \\
\hline & 0.293 & 0. & & 0.997 & 0.274 & 0.230 & 1.108 & 0.679 & 0.131 & 0.537 & 0.394 & 0 & 0.236 & & 0.849 & 0.99 & 0.087 & 0.55 & 1.02 & 0.12 & . & 15.6 & 1.6 & & 0.01 \\
\hline & 0.591 & 0.176 & 0.222 & 0.236 & 0.202 & 0.452 & 0.142 & 8.157 & 0.082 & 0.355 & 0.147 & 0.575 & 0.477 & 2687 & & 2700 & 0.075 & 0.169 & 0.263 & 0.077 & 0.088 & 0.822 & 18.352 & 1.980 & 0.005 \\
\hline & 0.175 & 0.196 & 0.103 & 0.261 & 0.283 & 1815 & 0.077 & 2090 & 0.037 & 0.48 & 0.402 & 0.189 & 0.157 & 1013 & 4.087 & & 0.083 & 0939 & 0.537 & 0.13 & 0.089 & 755 & 14855 & 15.875 & 0.015 \\
\hline Rural wer & 1.551 & 1871 & 4.070 & 0.419 & 0.050 & 0.084 & 0.043 & 0.087 & 4.132 & 0.695 & 0.100 & 0.298 & 0.352 & 0.098 & 0.027 & 0.049 & & 0.732 & 0.350 & 0.290 & 0.510 & 0.468 & 13131 & 1.890 & 0.105 \\
\hline Rura & 1.573 & 1029 & 1 & 265 & 0.392 & 0.136 & 0.116 & 0.095 & 0.699 & 3556 & 0.270 & 0.261 & 0.354 & 0 & 0.055 & 18 & 1078 & . & 1606 & 0.79 & 758 & & & & 131 \\
\hline & 0.524 & 0.377 & 0.341 & 0.407 & 6.598 & 5756 & 0.059 & 0.191 & 0.253 & 0.611 & 6.785 & 0.388 & 0.151 & 1.249 & 0.123 & 0.317 & 0.353 & 0.725 & & 0.649 & 0.599 & & & & .095 \\
\hline & 0.111 & 157 & 0 & 0.100 & 0.018 & 0.058 & 9.307 & 0.425 & 0.073 & 0.174 & 0.051 & 8.31 & 0.493 & 0.048 & 0.01 & 0.0 & 0.512 & 0.442 & 0.213 & & 4.608 & & 04 & & 0.068 \\
\hline & 0.507 & 0.724 & 0.293 & 0.288 & 0.034 & 0.054 & 0.148 & 0.068 & 0.291 & 0.440 & \begin{tabular}{|l|l|} 
\\
\end{tabular} & 0.586 & 17.346 & 0.063 & 0.015 & 0.019 & 0.529 & \begin{tabular}{|l|l|} 
& 0.831 \\
\end{tabular} & \begin{tabular}{|l|l|} 
& 0.678 \\
\end{tabular} & 3.738 & - & 0.519 & 0.303 & $0.17 / 7$ & 0.035 \\
\hline & 0.287 & 0.106 & & 0.227 & 0.459 & 0. & 0.057 & 0.446 & 0.118 & 0.315 & 0.255 & & 0.0 & 24.48 & 0.1 & $0: 3$ & 0.311 & 513 & 0.7 & 0.27 & 0.186 & & 0.65 & & \\
\hline & 0.090 & 0.044 & 0.076 & 0.552 & 0.047 & 0.153 & 0.034 & 21223 & 0.024 & 0.394 & $\mid 0.080$ & 0.268 & 0.120 & 3.522 & 21893 & 1000 & 0.292 & 0.762 & 0.287 & 0.313 & 0.291 & 1.811 & 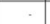 & 2965 & 0.033 \\
\hline & 0.190 & 0.13 & & & & & & 12 & 0.0 & 0. & 0.7 & & & & & 25.428 & & & & & & & & & 00 \\
\hline & 0.138 & \begin{tabular}{|l|l|l} 
& 0.156
\end{tabular} & 0.044 & 0.023 & 0.062 & 0.018 & 0.016 & 0.012 & 0.030 & 0.049 & \begin{tabular}{|l|l|} 
\\
\end{tabular} & 0.052 & 0.024 & 0.030 & 0.015 & 0.18 & 0.053 & \begin{tabular}{|l|}
0044 \\
\end{tabular} & \begin{tabular}{|l|l|} 
& 0.027 \\
\end{tabular} & 0.053 & 0.055 & 0.045 & 0.026 & 0.017 & \\
\hline
\end{tabular}

Notes: Grey column indicates intra-island migration. Source: Author's calculations

Table 5 Multiplicative component matrix of primary-educated migration, 2010

\begin{tabular}{|c|c|c|c|c|c|c|c|c|c|c|c|c|c|c|c|c|c|c|c|c|c|c|c|c|c|}
\hline & skarta & $\mid \begin{array}{l}\text { Onuer } \\
\text { searta }\end{array}$ & Banoung & wane & surbove & nossar & medan & vass & $\begin{array}{c}\text { Urtan } \\
\text { west } \\
\text { wave }\end{array}$ & & \begin{tabular}{|c|} 
Urbosn \\
$c a s$ \\
can \\
bas
\end{tabular} & & & trangan & $\begin{array}{l}\text { Urban } \\
\text { subuesi }\end{array}$ & neast & $\begin{array}{l}\text { Rural } \\
\text { west } \\
\text { wive }\end{array}$ & & \begin{tabular}{|c|} 
Ruara \\
east \\
save
\end{tabular} & $\begin{array}{c}\text { Rual } \\
\text { noman } \\
\text { Sumatera }\end{array}$ & $\begin{array}{c}\text { Aural } \\
\text { sovat } \\
\text { sumnatera }\end{array}$ & $\begin{array}{l}\text { Rural } \\
\text { Imanantan }\end{array}$ & $\begin{array}{c}\text { Runat } \\
\text { sulwesi }\end{array}$ & & \\
\hline tarta & & 3.276 & 0.726 & 0.548 & 0.242 & 0.176 & 455 & 0.291 & 1.131 & 1265 & 0.299 & 0.581 & 0.553 & 0.243 & 0.229 & 0.204 & 1.990 & 2.476 & 0.979 & 0.700 & 0.658 & 0.130 & 0.293 & 0.256 & 0.067 \\
\hline $\begin{array}{l}\text { Outer } \\
\text { banns }\end{array}$ & 2.876 & - & 240 & & 0.141 & 0.099 & 274 & & 2430 & 1097 & 0.269 & 0.404 & 0.620 & & 0.093 & 0.126 & 4.807 & 2.270 & C.791 & 0.735 & 106 & & & 251 & 103 \\
\hline Banoure & 0.954 & 1316 & 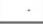 & 0.437 & 0.263 & 0.361 & 344 & 255 & 3.308 & 0.857 & 0.344 & 0.77 & 1.219 & 291 & 0.19 & 0.204 & 6.502 & 1.730 & 0.565 & 0.76 & 1.12 & & 0.26 & 0.293 & 103 \\
\hline semararg & 1.148 & 781 & 0.344 & & 0.480 & 0.230 & ${ }_{40}$ & & 0.466 & 3162 & 0.455 & 0.858 & 0.435 & & & 0.348 & 0.449 & & 1305 & 0.448 & & & & & 0.027 \\
\hline Suratose & 0.715 & 0.571 & 0.551 & 0.858 & ${ }^{\circ}$ & 1225 & 0.201 & 0.985 & 0.612 & 0.801 & 4.806 & 0.375 & 0.405 & 61 & $0 \pi n$ & 1.280 & 0.459 & 0.734 & 8017 & 0.23 & 0.41 & 1.07 & 0.65 & 1.521 & 0.028 \\
\hline Denosure & 0.198 & 0.998 & 0.375 & 0.49 & 1.207 & - & 0.229 & 608 & 0.274 & 0.556 & 7194 & 0.235 & 0.249 & & & 934 & 0.394 & 0618 & 13090 & 0.28 & 0.37 & & & & $\infty$ \\
\hline Msoden & 0.221 & 0.423 & 0.405 & 0.137 & 0.073 & 0.056 & & 0.056 & 0.281 & 0.152 & 0.086 & 4.023 & 0.623 & 1111 & 0.091 & 0.080 & 0.301 & 0.177 & 0.204 & 952 & 104 & .12 & 201 & 2.10 & 0.023 \\
\hline Malossur & 0.145 & 0.087 & 0. & & 0.1 & 0.115 & 0.042 & & 0.067 & 126 & 0.28 & 0.225 & 0.09 & & & & 0.0 & 0.080 & & & & & 44.286 & & 101 \\
\hline resonest & 1.575 & 1.998 & 2.418 & 0.703 & 0.167 & 0.143 & 0.243 & 0.166 & . & 0.762 & 0.235 & 0.458 & 0.836 & 0.176 & 0.123 & 0.111 & 3.875 & 1.070 & 0.495 & 0.377 & 0.716 & 0.297 & 0.269 & 0.218 & 0.034 \\
\hline Urtan & 2.355 & 1.546 & 0.845 & 2600 & 0.296 & 0.239 & 0.169 & 0.296 & 0.942 & . & 0.320 & 0.352 & 0.376 & 0.305 & 0.203 & 0.242 & 0.923 & 2990 & 0.689 & 0.318 & 0.597 & 0.43 & 27 & 362 & .080 \\
\hline $\begin{array}{c}\text { Ution east } \\
\text { 15ses }\end{array}$ & 0.171 & 0.17 & 0.176 & 0.250 & 5.470 & 8715 & 0.071 & 0.564 & 0.164 & 0.305 & - & 0.310 & 0.179 & 1509 & 0.254 & 0.741 & 0.124 & 0.336 & \begin{tabular}{|c|} 
\\
6948
\end{tabular} & 0.256 & 0.591 & 1.331 & 0907 & 2011 & 0.022 \\
\hline & 0.327 & 0.357 & 0.425 & 0.358 & 0.073 & 0.092 & 5703 & 0.101 & 0.291 & 0.304 & 0.219 & & 1.303 & 184 & & 132 & & & \begin{tabular}{|l|l|} 
& 0.651 \\
\end{tabular} & & & & & & \\
\hline & 0.807 & 0.645 & 0.481 & 0.327 & 0.080 & 0.099 & 0.587 & 0.122 & 0.504 & 0.502 & 0.379 & 1842 & $\cdot$ & 0.160 & 0.063 & 0.068 & 0.621 & 0.554 & \begin{tabular}{|l|l|l|} 
\\
\end{tabular} & 1.13 & 8.941 & 0.156 & 1236 & & 0.028 \\
\hline & 0.213 & 0.155 & & 0.343 & 0.420 & 0.120 & 0.087 & 1.224 & 0.159 & 0.996 & & 0 & 0.117 & & 0.993 & & & & & & & & & & \\
\hline & 0.099 & 0.073 & 0.083 & 0.096 & 0.122 & 0.155 & 0.053 & 5.637 & 0.072 & 0.175 & 0.320 & 0.187 & 0.095 & 1.896 & & 3.214 & 0.121 & 0.075 & $\mid 0.316$ & 0.038 & 0.093 & 0.812 & 21762 & 4.412 & 1013 \\
\hline 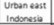 & 0.135 & 0.124 & & & & & & & & & & & & & & & 0.131 & & & & & & & & 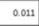 \\
\hline $\begin{array}{l}\text { Rutal west } \\
\text { lave }\end{array}$ & 1.758 & 1.832 & 4.098 & 0.299 & 0.112 & 0.133 & 0.084 & 0.071 & 3.600 & 0.505 & 0.135 & 0.357 & 0.525 & 0.131 & 0.082 & 0.105 & - & 0.669 & 0.316 & 0.35 & 0.72 & 0.323 & & & 1.10 \\
\hline & 1.552 & 2.191 & 1203 & 3.202 & 0.385 & 0.123 & 0.148 & 0.171 & 0.824 & 3355 & 0.2200 & 0.000 & 0.454 & & & 0.162 & 0.759 & & C.858 & & & & & & \\
\hline & 0.499 & 0.351 & 0.243 & 0.493 & 6.598 & 3.499 & 0.100 & 0.412 & 0.258 & 0.625 & 5.870 & 0.490 & 0.210 & 1597 & 0.304 & 0.662 & 0.211 & 0,690 & & 0.421 & 0.69 & 1.64 & & & 0.101 \\
\hline & 0.133 & & & & & 0.039 & 14.571 & & 0.190 & & & 10372 & & & & & 0.299 & 63 & & & 2.383 & & & & \\
\hline & 0.779 & 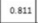 & 0. & 0.4 & 0.071 & 0.071 & 0.263 & 0.052 & 0.543 & 0.559 & 0.298 & 0.85 & 15.631 & Q94 & 0.0 & Sid & & & 1 & 2113 & & 0.248 & & & .036 \\
\hline & 0.243 & 0.175 & 0.125 & 0.407 & 0.242 & 0.078 & 0.069 & 0.422 & 0.186 & 0.432 & 0.488 & & 194 & 17.977 & 0.249 & 255 & 0.325 & 230 & \begin{tabular}{|l|l|l|} 
\\
\end{tabular} & .455 & 0.264 & & 2123 & 2.75 & 0.020 \\
\hline & 0.050 & 0.025 & & & 0.0 & 0.0 & & 13739 & 0.0 & & 0.107 & & & & 177.764 & .95 & 0.0 & & 0.2 & & 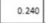 & & & 829 & 0.040 \\
\hline & 0.194 & 0.144 & & & 0.709 & 2740 & 0.1 & 4.010 & 0.061 & 0.272 & 0.693 & & 0.150 & & 1.223 & 18668 & 0.117 & 79 & 0.637 & & & 20.022 & & & 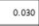 \\
\hline & 0.1 & & & & & & & & & & & & & & & 0.022 & & 0.035 & & 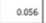 & 0.052 & $\infty 2$ & 0.025 & 0.025 & \\
\hline
\end{tabular}

Notes: Grey column indicates intra-island migration. Source: Author's calculations 
Table 6 Multiplicative component matrix of secondary-educated migration, 2000

\begin{tabular}{|c|c|c|c|c|c|c|c|c|c|c|c|c|c|c|c|c|c|c|c|c|c|c|c|c|c|}
\hline $\operatorname{man} x$ & atasta & \begin{tabular}{|} 
over \\
sarasto to
\end{tabular} & mane & rare & rosora & Denasess & meston & arsost & $\begin{array}{c}\text { Urtan } \\
\text { wer } \\
\text { aroo }\end{array}$ & & $\begin{array}{l}\text { Urbon } \\
\text { ess } \\
\text { daro }\end{array}$ & & $\begin{array}{l}\text { Urben } \\
\text { sach } \\
\text { sumotere }\end{array}$ & Kurben & titon & $\begin{array}{l}\text { ban eses } \\
\text { donnessos }\end{array}$ & \begin{tabular}{|l|} 
Rurat \\
west \\
toro
\end{tabular} & 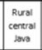 & \begin{tabular}{|l|} 
Rural \\
eas \\
tore
\end{tabular} & $\begin{array}{c}\text { Aurat } \\
\text { noth } \\
\text { sumberes }\end{array}$ & $\begin{array}{c}\text { Aural } \\
\text { sonen } \\
\text { sumberer }\end{array}$ & $\begin{array}{c}\text { Riual } \\
\text { Kolmostan }\end{array}$ & $\begin{array}{l}\text { Rurar } \\
\text { Sulawes }\end{array}$ & 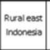 & $\begin{array}{c}\text { Origin } \\
\text { comp. }\end{array}$ \\
\hline Iaberto & & 3.374 & 0.798 & 0.561 & 0.198 & 0.47 & 0.359 & 0.112 & 1.155 & 0.629 & 0.289 & 0.325 & 0.771 & 0.27 & 0.205 & 0.225 & 1120 & 1.28 & 0,037 & 0.490 & 0.416 & 0.182 & 0.242 & 0.398 & 0.120 \\
\hline Outer & 3916 & & 1.930 & 0.488 & 0.147 & 0.246 & 0.278 & 0.098 & 3.011 & 0816 & $\mid 0.271$ & 0.245 & 0.633 & 0.218 & 0.112 & 0.325 & $5.132 \mid$ & 17966 & Oss1 & 0.642 & 1.005 & 0.261 & 0.205 & 0.727 & 0.035 \\
\hline Bendars & 1521 & 1.428 & . & 0.562 & 0.262 & 0514 & 0.413 & 0.220 & 3.616 & 0.752 & 0.500 & 0.588 & 0.685 & 0.43 & 0.219 & 0.272 & 5.669 & 1.346 & 0.724 & 0.515 & 0.76 & 0.447 & 0.273 & 0.55 & 0.029 \\
\hline Semarere & 1993 & 67 & 0.793 & & 0.869 & 0.475 & 0.129 & 0.133 & 2081 & 3.599 & 0.952 & 0.736 & 0.363 & 0.586 & 0.171 & 0.235 & 0.875 & 470 & 1.197 & 0.277 & 0.486 & 1.025 & 0.261 & 0.537 & 0.025 \\
\hline surobore & 1.121 & a & 0597 & 2006 & . & 2855 & 0.248 & 0.691 & 0.557 & 0.005 & 8.208 & 0.456 & 0.308 & 215 & 0.72 & 1.081 & 0.490 & 1036 & 11400 & 0.259 & 0.34 & 1.570 & 0.793 & 193 & $102=$ \\
\hline Derroserar & 0.750 & 0.351 & 0.915 & 0.637 & 0.876 & . & 0.109 & 0.558 & 0.240 & 1778 & 5.301 & 0.197 & 0.394 & 0.67 & 0.508 & 4.219 & $|0.270|$ & 0.584 & 11924 & 0.193 & 0.295 & 0.549 & 2.325 & 7.427 & 0.005 \\
\hline Medan & 1.138 & 618 & 0.941 & 0.218 & 0.100 & 0.150 & & 0.071 & 0.427 & 0.448 & \begin{tabular}{|l|l|}
0.108 \\
\end{tabular} & 3.94 & 1014 & 0315 & 0.105 & 0.132 & 0.415 & 0.197 & 0.119 & 5.74 & 1.06 & 0.28 & 01 & & 5 \\
\hline Matararat & 0.705 & 0.067 & 0.541 & 0.341 & 0.352 & 0.499 & 0.133 & - & 0.069 & 0.657 & 0.443 & 0.378 & 0.184 & 239 & 7.190 & 2388 & 0.036 & 0.419 & 0.510 & 0.110 & 0.16 & 1.1993 & 26042 & 4589 & 0.011 \\
\hline 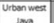 & 1.974 & 1.798 & 3021 & 0.698 & 0.245 & 0.120 & 0.094 & 0.041 & & 0.885 & 0.235 & 0.258 & 0.315 & 0.165 & 0.068 & 0.069 & 4.35s & 0.671 & 0267 & 0.189 & 0.31 & 0.180 & 2.100 & 0.191 & 2027 \\
\hline Uirton & 1999 & 1.233 & 0.879 & 4.398 & 0.483 & 0.457 & 0.087 & 0.123 & 1991 [ & . & 0.515 & 0.877 & 0.308 & 0.490 & 0.116 & 0.239 & 1052 & 4.993 & 0.921 & 0.296 & 0.537 & 0.750 & 0.195 & 0.456 & 0.076 \\
\hline & 0.555 & 0.341 & 0.435 & asse & 7237 & 5049 & 0.060 & 0.299 & 0.307 & 0.720 & . & 1019 & 0.169 & 154 & 0.26 & 0.651 & 0.306 & 0.396 & 6.377 & 0.208 & 0.42 & 1.404 & 0.494 & & \\
\hline & 1.211 & \begin{tabular}{|l|l|}
0.507 \\
\end{tabular} & 1.167 & 0.334 & 0.085 & 0.187 & 5.641 & 0.241 & 0.400 & 0.708 & 0.180 & . & 2242 & 0.233 & 0.097 & 0.118 & 0.364 & 0.345 & 0.224 & 8.727 & 1.109 & 0.204 & 0.122 & 0.225 & 0.047 \\
\hline 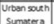 & 1.135 & 0.722 & 1.267 & 0.369 & 0.115 & 0.135 & 0.327 & 0.079 & 0.596 & 12200 & 0.162 & 1575 & & 0.17 & 0.059 & 0.073 & 0.692 & 0.448 & 0.204 & 1.041 & 9.45 & 0.177 & 2.106 & 2075 & 0.043 \\
\hline Uvion & 0.600 & 0.204 & 0.597 & 0.661 & 0.367 & 0.298 & 0.147 & 0.721 & 0.178 & 1778 & 0.680 & 0.178 & 0.219 & 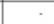 & 0.736 & 0.425 & 0.187 & 0.664 & 1060 & 0.147 & 0.161 & 21215 & 1.330 & 0.964 & 0.018 \\
\hline Uiton & 1.158 & 0.246 & 0.483 & 0.985 & 0.318 & 0.498 & 0.147 & 5.966 & 0.162 & 0.614 & 0.321 & 0.95 & 0.358 & 228 & & 2399 & 0.087 & 0.225 & 0.291 & 0.113 & & & 20.200 & 2349 & 0.01 \\
\hline Uiton east & 0.684 & 0.140 & 0.469 & 0.666 & 0.445 & 2177 & 0.079 & 2.927 & 0.052 & 1.115 & \begin{tabular}{|l|l|} 
& 0.599 \\
\end{tabular} & 0.161 & 0.180 & 0.953 & 5.838 & & 0.072 & 0.551 & 1187 & 0.158 & 0.135 & 0.428 & 10.542 & 19.676 & 0.016 \\
\hline Ruxalinese & 1572 & 1.514 & 4544 & 0.306 & 0.085 & 0.111 & 0.048 & 0.045 & 4.622 & 0.708 & 0.128 & 0.183 & 0.287 & 0.131 & 0.044 & 0.078 & & 0.832 & 0.450 & 0.160 & & & & & \\
\hline & 1401 & 1.054 & 0.883 & 1451 & 0.451 & 0.156 & 0.060 & 0.063 & 0959 & 3500 & 0.539 & 0.350 & 0.181 & 0.27 & 0.048 & 0.126 & 1056 & & 1154 & 0.334 & 0.459 & 0.685 & 0.151 & 0.355 & 0.099 \\
\hline and & 0.674 & 0.480 & 0.055 & 0.469 & 7568 & 62888 & 0.057 & 0.156 & 0.365 & 0.823 & \begin{tabular}{|l|l|} 
\\
\end{tabular} & 0.437 & 0.137 & & 0.120 & 0.427 & 0.0811 & 0.887 & & 0.333 & 0.456 & 827 & 24 & & 2007 \\
\hline & 0.292 & 0.192 & 0.269 & 0.087 & 0.037 & 0.074 & 7989 & 0.073 & 0.128 & 0.197 & 0.05s & 5916 & 0.528 & 0.12 & 0.023 & 0.052 & 0.304 & 0.236 & 0.125 & & 2479 & 0.205 & 0.190 & 0.227 & 0.078 \\
\hline & 0.637 & 0. & 0.559 & 0. & 0.0 & 0.081 & 0.153 & 0.021 & 0.3866 & 0.811 & 0. & 755 & 16.065 & 0.069 & 017 & 0.029 & $|0.847|$ & 0.550 & 0.338 & | & & 0.187 & 139 & 1096 & 0.037 \\
\hline & 0.339 & \begin{tabular}{|l}
0.096 \\
\end{tabular} & 0.185 & 0.298 & 0.095 & 0.209 & 0.091 & 0.161 & 0.083 & 0.684 & \begin{tabular}{|l|l|l|} 
\\
\end{tabular} & 0.098 & 0.028 & 22580 & 0.099 & 0.178 & 0.211 & 0.534 & 0.555 & 0.192 & 0.079 & & 0.466 & 0.985 & 0.020 \\
\hline & 0.142 & & 0.107 & 0.1 & 0.057 & 0.197 & 0.029 & 15.889 & 0.025 & 0.241 & 0.1 & 0.5 & 0.0 & & 15.058 & 0.695 & 0.109 & 0.357 & 0.161 & 0.142 & 0.106 & 1.427 & & 1953 & 0.08 \\
\hline & 0.470 & 0.259 & 0.311 & 0.32 & 0.419 & 2037 & 0.050 & 1.459 & 0.0822 & 0.888 & 0.448 & 0.267 & 0.062 & 0.683 & 1.030 & 22.143 & 0.27 & 0.627 & 0.057 & 0.144 & 0.104 & 1.007 & 3.002 & $\because$ & 0.03 \\
\hline & 0.102 & \begin{tabular}{|l|l|} 
\\
\end{tabular} & 0.055 & 0. & 0.039 & 0.019 & 0.027 & 0.028 & 0.027 & 0.005 & 0.010 & 0.094 & 0.029 & & 0.021 & 0.023 & \begin{tabular}{|c|c|} 
\\
\end{tabular} & 0.021 & 0.016 & 0.037 & 0.031 & 0.024 & 0.028 & 0.012 & \\
\hline
\end{tabular}

Notes: Grey column indicates intra-island migration. Source: Author's calculations

Table 7 Multiplicative component matrix of secondary-educated migration, 2010

\begin{tabular}{|c|c|c|c|c|c|c|c|c|c|c|c|c|c|c|c|c|c|c|c|c|c|c|c|c|c|}
\hline 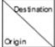 & masta & 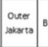 & Bemane & enzarare & srroosere & Denoseses & mestion & Matroso & 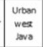 & 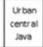 & 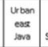 & 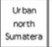 & 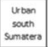 & $\begin{array}{l}\text { vitom } \\
\text { rammeran }\end{array}$ & $\operatorname{uim}_{\text {sitame }}$ & 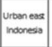 & 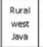 & $\mid$ & 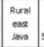 & 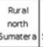 & 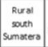 & $\begin{array}{l}\text { Ruxal } \\
\text { Kathorater }\end{array}$ & $\mid \begin{array}{c}\text { Ruras } \\
\text { swowes }\end{array}$ & 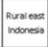 & $\begin{array}{c}\text { orizin } \\
\text { compe. }\end{array}$ \\
\hline dorto & & 3.569 & 0.995 & 0.482 & 0.238 & 0.37 & 0.297 & 0.15 & 1016 & 0.603 & \begin{tabular}{|l|}
0.218 \\
\end{tabular} & 0.356 & 0.482 & 0.291 & 0.227 & 0.175 & 1223 & \begin{tabular}{|l|l|l}
1395 \\
\end{tabular} & 0.512 & 0.662 & 0.559 & 0.211 & 0.355 & 0.363 & 0.009 \\
\hline Oneer & 4358 & & 247 & Obese & 0.235 & 027 & 0.241 & 0.07 & 2954 & 2,182 & 0.298 & 0.289 & 0.621 & 0.220 & 0.127 & 0.142 & 3,769 & 3.0055 & 0080 & 0.8666 & 1.996 & 0.225 & 0.377 & 0.999 & 0.093 \\
\hline Bamarere & 1.554 & \begin{tabular}{|l}
1.528 \\
\end{tabular} & & 0,420 & 0.324 & 0.80 & 0.320 & 0.21 & 4.047 & 0,786 & 0.283 & 0.560 & 0.033 & 0.452 & 0.196 & 0.220 & 6.173 & \begin{tabular}{|l|}
157 \\
\end{tabular} & \begin{tabular}{|l}
0.627 \\
\end{tabular} & 0.761 & 1020 & 0.498 & 0.973 & 0.496 & 0.025 \\
\hline Semarare & 1516 & \begin{tabular}{|l|l|} 
o.sen \\
\end{tabular} & 0.667 & & 0.788 & 0.57 & 0.172 & 0.17 & 0.977 & s.16 & 0.004 & 0.591 & 0.39 & 0.626 & 0.223 & 0.288 & 0.876 & \begin{tabular}{|l|l|}
5007 \\
\end{tabular} & \begin{tabular}{|l|l}
1071 \\
\end{tabular} & 0.375 & 0.829 & 1.50 & 0.542 & 1087 & 0.019 \\
\hline sratarero & 0.819 & 0.455 & 0.525 & 0.87 & . & 219 & 0.162 & 0.49 & 0.359 & aros & 16520 & 0.339 & 0.251 & 1.633 & 0.654 & 0.979 & 0.450 & 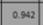 & 10052 & 0.223 & 0.322 & 1.417 & 0.818 & 1871 & 0.025 \\
\hline Derpasar & 0.55 & 0.254 & 0.874 & 0626 & 1847 & 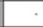 & 0.111 & 0.40 & 0.23 & 1065 & 31.158 & 0.185 & 0.92 & 0.008 & 0.998 & 1.296 & 0.3500 & $\mid 0.821$ & 13. & 0.217 & 0.354 & 0.313 & 1.421 & 46.618 & 00005 \\
\hline nearen & 0.814 & \begin{tabular}{|l|l|} 
\\
\end{tabular} & 0.978 & 02000 & 0.123 & 0.19 & & 0.05 & 0.533 & 0.286 & \begin{tabular}{|l|l|} 
\\
\end{tabular} & 3618 & 0.79 & 0.305 & 0.102 & 0.122 & 0.74 & \begin{tabular}{|l|l|l|} 
\\
\end{tabular} & \begin{tabular}{|l|l|l|} 
\\
\end{tabular} & 6.059 & 1333 & 0.048 & 0.138 & 0.216 & 0.038 \\
\hline $\operatorname{sinas}$ & 0.555 & 0.198 & 0.608 & 02214 & 0.524 & 0.38 & 0.099 & & 0.126 & 0.340 & 0.320 & 0.304 & 0.119 & 1910 & 4.883 & 2.494 & 0.173 & \begin{tabular}{|l|l|l|} 
\\
\end{tabular} & \begin{tabular}{|c|}
0.36 \\
\end{tabular} & 0.075 & 0.087 & 1.607 & 15.631 & 6.300 & 0.021 \\
\hline 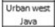 & $17 m$ & 2.801 & 4.231 & 0.592 & 0.220 & 020 & 0.071 & 0.06 & & 1051 & 0.102 & 0267 & 0.38 & 0.167 & 0.076 & 0.0900 & 4.9653 & \begin{tabular}{|l|l|l}
1263 \\
\end{tabular} & 0.426 & 0.281 & 0.355 & 0.254 & 0.2009 & 0.207 & 0.025 \\
\hline & 2.078 & 1.553 & 0.814 & 4so1 & 0.974 & 0.42 & 0.077 & 0.13 & 1.203 & & 0.318 & 0.618 & 0.901 & 0.391 & 0.138 & 0.186 & 10000 & \begin{tabular}{|l|l}
4052 \\
\end{tabular} & \begin{tabular}{|l}
0766 \\
\end{tabular} & 0.260 & 0.555 & 0.752 & 0.272 & 0.512 & 0.062 \\
\hline & 0.315 & \begin{tabular}{|l}
0.262 \\
\end{tabular} & 0.015 & 0,324 & 8003 & 792 & 0.022 & 0.19 & 0.246 & 0.527 & & 0.276 & 0.133 & 1202 & 0.255 & 0.455 & 0.195 & 0,0420 & 20019 & 0.178 & 0.976 & 1.455 & 0.5866 & 2976 & 0.022 \\
\hline 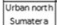 & 0.832 & \begin{tabular}{|l|l|c|} 
\\
\end{tabular} & 1.128 & 0.310 & 0.137 & 0.16 & 4856 & 0.08 & 0.559 & 0.063 & \begin{tabular}{|l|l|l|} 
\\
\end{tabular} & & 1211 & a. & 0.077 & 0.096 & 0.4511 & \begin{tabular}{|l|l}
0.599 \\
\end{tabular} & |0.554 & 10.307 & & & & 0.369 & 0.045 \\
\hline seret & 1.206 & 0.7900 & 1.222 & 0418 & 0.226 & 0.15 & 0.085 & 0.06 & \begin{tabular}{|l|l} 
\\
\end{tabular} & 1003 & 0.288 & 1062 & . & 0.205 & 0.069 & 0.0018 & 11300 & 0.0433 & 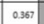 & 0.888 & 11992 & 0.216 & 0.128 & 0.123 & 0.035 \\
\hline & 0.521 & \begin{tabular}{|l|l}
1966 \\
\end{tabular} & 0.5800 & 0.515 & 0.787 & 0.212 & 0 coss & 0.85 & 0.157 & $120 \mathrm{~s}$ & 18500 & 0.126 & 0.165 & . & 0.5977 & 0.199 & 0.198 & $\mid 0<81$ & \begin{tabular}{|l|l|l}
1774 \\
\end{tabular} & 0.156 & 0.135 & 17278 & 2.452 & 0.625 & 00000 \\
\hline Asmes & 0.098 & 0.136 & 0.333 & 0.200 & 0.284 & 0.36 & 0.090 & 6.79 & 0.085 & 0.315 & \begin{tabular}{|l|l|l|} 
\\
\end{tabular} & 0.180 & 0.067 & 1334 & . & 1987 & 0.1000 & \begin{tabular}{|l|l|l|} 
\\
\end{tabular} & \begin{tabular}{|l|l|l}
0.903 \\
\end{tabular} & 0.053 & 0.068 & 1.033 & 23.554 & 3.588 & 0.017 \\
\hline aresen & 0.459 & \begin{tabular}{|l|l|l}
0.178 \\
\end{tabular} & 0.473 & 0.721 & 0.793 & 163. & 0.079 & 3.01 & 0.107 & 1098 & \begin{tabular}{|l|l}
1.270 \\
\end{tabular} & 0.142 & 0.149 & 0.3800 & 1.874 & & \begin{tabular}{|l|l|l|} 
\\
\end{tabular} & \begin{tabular}{|l|l|l|} 
\\
\end{tabular} & 0.925 & 0.075 & 0.124 & 0.0489 & 2.593 & 23550 & 0.019 \\
\hline & 1921 & 1.009 & 4.637 & $0,2 \times 2$ & 0.127 & 0.20 & 0.009 & 0.06 & 4.612 & 0.615 & 0.116 & 0.190 & 0.290 & 0.146 & 0.065 & 0.059 & & 0.657 & o. 0352 & 0.214 & 0.515 & 0.280 & 0.152 & 0.185 & 0.058 \\
\hline & 1528 & 1.360 & 0.757 & 3245 & 0.202 & 020 & 0.033 & 0.06 & 1288 & 37009 & \begin{tabular}{|l|l|l} 
\\
\end{tabular} & 0.378 & 0.203 & 0.254 & 0.064 & 0.123 & 0.905 & & 0.737 & 0.253 & 0.590 & 0.929 & 0.202 & 0.366 & 0.103 \\
\hline & 0.584 & 0.441 & 0.315 & 0,288 & 6900 & $5 \pi$ & 0.0048 & 0.15 & 0.34 & 0.035 & 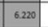 & 0.457 & 0.199 & 10000 & 0.159 & 0.372 & 0.322 & \begin{tabular}{|l}
0.700 \\
\end{tabular} & . & 0.248 & 0.484 & 1.591 & 0.469 & 1003 & 0.085 \\
\hline & 0.283 & \begin{tabular}{|l|l|} 
\\
\end{tabular} & 0.345 & 0.203 & 0.059 & 0.06 & 7994 & 0.022 & 0.185 & 0.255 & 0.073 & 6224 & 0.000 & 0.112 & 0.024 & 0.034 & |0.35s & \begin{tabular}{|l|l|l|} 
\\
\end{tabular} & \begin{tabular}{|l|l}
0.199 \\
\end{tabular} & . & 1.231 & 0.800 & 0.0977 & 0.120 & 0.084 \\
\hline & 0,700 & \begin{tabular}{|l|l|} 
\\
\end{tabular}, 76 & 0.495 & 0265 & 0.074 & 0.098 & 0.135 & 0.02 & 0.435 & 0.850 & 0.165 & 0.082 & 15802 & 0.075 & 0.021 & 00000 & 2,155 & \begin{tabular}{|c|c|c|} 
\\
\end{tabular} & \begin{tabular}{|l|l|} 
\\
\end{tabular} & 0.891 & . & 0.198 & 0.005 & 0005 & 0.004 \\
\hline & 0.530 & \begin{tabular}{|l|l}
0.133 \\
\end{tabular} & 0.195 & 0.489 & 0.178 & 010 & 0.003 & 0.25 & 0.056 & 0.850 & 0.8020 & 0003 & 0.056 & 20139 & 0.119 & 0.065 & 0.207 & \begin{tabular}{|l|l|l} 
\\
\end{tabular} & \begin{tabular}{|l|l|l|} 
\\
\end{tabular} & 0.189 & 0.134 & & 0.695 & 0.319 & 0.027 \\
\hline & 0.108 & \begin{tabular}{|l|l|}
0.038 \\
\end{tabular} & 0.107 & 0.093 & 0.084 & 0.09 & 0.006 & 12.42 & 0.029 & 0.247 & 0.076 & 0. & 0.016 & 1.165 & 15.599 & 0.784 & 0.057 & 0.0565 & \begin{tabular}{|l|l|l}
0.171 \\
\end{tabular} & 0.030 & 0.051 & 1.502 & & 2388 & 0.099 \\
\hline & 0.361 & 0.142 & 0.226 & 0.458 & 0.558 & 163 & 0.044 & 2.60 & 0.064 & 0.837 & \begin{tabular}{|l|l} 
\\
\end{tabular} & 0.162 & 0.0 & 0.322 & 0.830 & 15394 & 0.105 & \begin{tabular}{|l|l|}
0.286 \\
\end{tabular} & \begin{tabular}{|l|l} 
& 0.75 \\
\end{tabular} & 0.074 & 0.079 & 0.733 & 1.436 & & 0.048 \\
\hline & 0.003 & \begin{tabular}{|l|}
0.180 \\
\end{tabular} & 0.047 & 0028 & 0.086 & 0.02 & \begin{tabular}{|l|l|}
0227 \\
\end{tabular} & 0.02 & 0.028 & |0.71 & 0.028 & 0.096 & 0.0927 & 0.036 & 0.023 & 0.066 & $\mid 0.018$ & \begin{tabular}{|l|l|} 
& 0.018
\end{tabular} & \begin{tabular}{|l|}
0.280 \\
\end{tabular} & & $0.028 \mathrm{~B}$ & 0.0300 & 0.018 & \begin{tabular}{|l|l|}
0.019 \\
\end{tabular} & \\
\hline
\end{tabular}

Notes: Grey column indicates intra-island migration. Source: Author's calculations 
Table 8 Multiplicative component matrix of tertiary-educated migration, 2000

\begin{tabular}{|c|c|c|c|c|c|c|c|c|c|c|c|c|c|c|c|c|c|c|c|c|c|c|c|c|c|}
\hline teannexion & tar ta & $\left|\begin{array}{l}\text { Oreer } \\
\text { sastate }\end{array}\right|$ & Banoure & senzare & suroose & Dencoser & meson & Matassere & $\begin{array}{l}\text { Uitean } \\
\text { wes } \\
\text { havo }\end{array}$ & \begin{tabular}{|c|} 
Uresson \\
certrat \\
soro
\end{tabular} & $\begin{array}{l}\text { urbos } \\
\text { eas } \\
\text { soro }\end{array}$ & \begin{tabular}{|c} 
uroson \\
north \\
sumserer
\end{tabular} & $\begin{array}{c}\text { Urtan } \\
\text { soun } \\
\text { sumeter }\end{array}$ & $\begin{array}{c}\text { Uibson } \\
\text { ratmstran }\end{array}$ & \begin{tabular}{|l} 
Sutson \\
sursures
\end{tabular} & \begin{tabular}{|c|} 
Urbas eas \\
insoness
\end{tabular} & $\begin{array}{l}\text { Rurat } \\
\text { wer } \\
\text { tave }\end{array}$ & 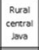 & \begin{tabular}{|c|} 
Rurat \\
ess \\
soro
\end{tabular} & $\begin{array}{c}\text { surat } \\
\text { sorth } \\
\text { sumerere }\end{array}$ & $\begin{array}{c}\text { Rurat } \\
\text { scumn } \\
\text { summerer }\end{array}$ & \begin{tabular}{|c|c|} 
Rusal \\
Kalmaven
\end{tabular} & \begin{tabular}{|c|} 
Rural \\
Suaveres
\end{tabular} & $\begin{array}{l}\text { Ruratean: } \\
\text { insoress }\end{array}$ & $\begin{array}{l}\text { Origin } \\
\text { comp. }\end{array}$ \\
\hline Jaserto & - & 2868 & 0.751 & 0.560 & 0.362 & 0.683 & 0.571 & 0.285 & 0.833 & 0.581 & 0.27 & 0.651 & 0.590 & 0.640 & 0.420 & 0.410 & 0.672 & 0.356 & 0.233 & 0.225 & 0.324 & 0.230 & 0.171 & 0.268 & 0.22 \\
\hline $\begin{array}{l}\text { Outer } \\
\text { joktorso }\end{array}$ & 4298 & . & 2.13 & 0.611 & 0.337 & 0.343 & 0.537 & 0.224 & 2351 & 0.790 & 0.260 & 0.499 & 0.833 & 0.553 & 0.439 & 0.535 & 4.205 & 0.615 & 0.427 & 0.425 & 0.527 & 0.323 & 0.187 & 0.458 & 0.038 \\
\hline Banare & 1792 & 1011 & - & 0.533 & 0.421 & 0.590 & 0.783 & 0.419 & 3.686 & 0.681 & 0.468 & 0912 & 1.221 & 0.836 & 0.568 & 0.559 & 5.127 & 0.550 & 0.428 & 0.399 & 0.650 & 0.420 & 0.261 & 0.527 & 0.05 \\
\hline sentrone & 1.209 & 0.536 & 1.015 & 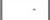 & 0.863 & 0.790 & 0.306 & 0.255 & 0.940 & 4.426 & 0.759 & 0.704 & 0.714 & 0.861 & 0.363 & 0.431 & 0.405 & 4.901 & 0.792 & 0.209 & 0.576 & 0.732 & 0.230 & 0.334 & 0.03 \\
\hline Surabere & 1.152 & 0.461 & 0.755 & 2068 & . & 2769 & 0.310 & 0.835 & 0.585 & 0.996 & 5.661 & 0,774 & 0.374 & 1783 & 0.661 & 2.399 & 0.311 & 0.790 & 7.668 & 0.183 & 0.341 & 0.963 & 0.539 & 1999 & 0.04 \\
\hline Derous & 11119 & 0.995 & 0912 & 0.728 & 1626 & . & 0310 & 0.614 & 0.24 & 2.25 & 2982 & 0.585 & 0.572 & 0.805 & 0.682 & 4.872 & 0.221 & 0.430 & 7167 & 0.163 & 0.182 & 0.500 & 0.903 & 4748 & 0.008 \\
\hline Meden & 1549 & \begin{tabular}{|l|l|} 
& 0.505 \\
\end{tabular} & 0.937 & 0.216 & 0.181 & 0.261 & - & 0.158 & 0.457 & 0.367 & 0.194 & $4 \cos$ & 1.375 & 0.620 & 0.165 & 0.346 & 0.263 & 0.168 & 0.116 & 6.079 & 1.075 & 0.426 & 0.094 & 0.16 & 0.04 \\
\hline Mas & 0.709 & 0.049 & 0.350 & 0.276 & 0.445 & 0.593 & 0.108 & - & 0.041 & 0.637 & 0.254 & 0.065 & 0.136 & 2.161 & 7.421 & 2321 & 0.013 & 0.191 & 0.218 & 0.074 & 0.108 & 0.967 & 18404 & 2811 & 0.028 \\
\hline 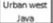 & 1315 & 1569 & 3.785 & 0.805 & 0.432 & 0369 & 0.201 & 0.098 & . & 0.795 & 0.234 & 0.307 & 0.363 & 0.447 & 0.172 & 0.196 & 5069 & 0.585 & 0.181 & 0.166 & 0.212 & 0.257 & 0.099 & 0.171 & 0.02 \\
\hline untorn & 1575 & 0.707 & 0.85 & 3877 & 0.660 & 0.656 & 0.387 & 0.264 & 1027 & . & 0.719 & 0.769 & 1.020 & 2.068 & 0.358 & 0.709 & 0.801 & 5.226 & 0.922 & 0.323 & 0.871 & 1.064 & 0.214 & 0.795 & 0.08 \\
\hline Uutran eass & 0.530 & 0.311 & 0.509 & 0.702 & 6.399 & 3226 & 0.156 & 0.497 & 0.372 & 0.858 & - & 0.697 & 0.367 & 1.618 & 0.522 & 1389 & 0.318 & 0.569 & 7376 & 0.280 & 0.457 & 0.926 & 0.328 & 2030 & 0.03 \\
\hline naterth & 1320 & 0.448 & 1.07 & 0.306 & 0.147 & 0.179 & 5.097 & 0.383 & 0.379 & 0.492 & 0.181 & . & 2442 & 0.393 & 0.229 & 0.225 & 0.295 & 0.262 & 0.116 & 8.877 & 1.357 & 0.265 & 0.063 & 0.108 & 0.05 \\
\hline $\begin{array}{l}\text { Uutran south } \\
\text { Sumserse }\end{array}$ & 1.286 & 0.488 & 1.246 & 0,431 & 0.178 & 0.199 & 0.523 & 0.195 & 0.601 & 0.786 & 0.264 & 1613 & & 0.404 & 0.138 & 0.166 & 0.556 & 0.381 & 0.163 & 0.708 & 11.493 & 0.198 & 0.041 & 0.123 & 0.03 \\
\hline $\begin{array}{l}\text { Uriton } \\
\text { Katmenten }\end{array}$ & 0.646 & 0.249 & 0.737 & 0.541 & 0.607 & 0.375 & 0.225 & 0.670 & 0.197 & 2012 & 0.910 & 0.280 & 0.402 & . & 0.557 & 0.407 & 0.242 & 0.575 & 0.595 & 0.115 & 0.144 & 19.658 & 0.315 & 0.210 & 0.02 \\
\hline Utiton & 1324 & \begin{tabular}{|l|l} 
\\
\end{tabular} & 0.707 & 0.299 & 0.389 & 0.700 & 0.180 & 5.662 & 0.197 & 0.616 & 0.388 & 0.4A1 & 0.468 & 1.331 & & 1.001 & 0.108 & 0.248 & 0.209 & 0.224 & 0.12 & 0.577 & 16.054 & 1286 & 0.01 \\
\hline 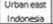 & 0.813 & 0.105 & 0.56 & 0.672 & 0.735 & 1.960 & 0.351 & 2.841 & 0.032 & 1063 & 0.840 & 0.224 & 0.369 & 0.934 & 3.528 & - & 0.087 & 0.45 & 0.978 & 0.159 & 0.079 & 0.304 & 2.838 & 21996 & 0.01 \\
\hline Rurol wer & 1263 & 1.098 & 6.10 & 0.387 & 0.211 & 0.207 & 0.104 & 0.131 & 5811 & 0.745 & 0.129 & 0.263 & 0.450 & 0.293 & 0.213 & 0.192 & . & 0.633 & 0.335 & $\begin{array}{l}0.181 \\
0\end{array}$ & 0.403 & 0.280 & 0.131 & 0.369 & 0.032 \\
\hline Auro & 1.061 & 0.614 & 0.922 & 4642 & 0.585 & 0.997 & 0.216 & 0.216 & 0.845 & 5.327 & 0.37 & 0.343 & 0.414 & 0.568 & 0.191 & 0.375 & 2132 & . & 1384 & 0.245 & 0.587 & 0.759 & 0.160 & 0.395 & 0.052 \\
\hline & 0.515 & 0.312 & 0.465 & abses & 7220 & 5305 & 0.182 & $0.3 a_{1}$ & 0.480 & 1050 & 7200 & 0.434 & 0.278 & 1.138 & 0.265 & 0.734 & 0.002 & 0.851 & . & 0.255 & 0.525 & 1.106 & 0.045 & 1309 & 0.05 \\
\hline & 0.579 & \begin{tabular}{|l|l|} 
& 0.201
\end{tabular} & 0.412 & 0.153 & 0.082 & 0.144 & 10870 & 0.153 & 0.229 & 0.345 & 0.101 & 82265 & 0.791 & 0.274 & 0.063 & 0.139 & 0.483 & 0.189 & 0.196 & - & 2330 & 0.343 & 0.178 & 0.227 & 0.035 \\
\hline & 0.913 & 0.408 & 1.059 & 0.309 & 0.152 & 0.181 & 0.437 & 0.054 & 0.473 & 0.919 & 0.158 & ת & 17.843 & 0.178 & 0.046 & 0.069 & 0.569 & 0.394 & 0.295 & 1.644 & . & 0.288 & 0.190 & 0.133 & 0.01 \\
\hline & 0.597 & 0.155 & 0.399 & 0.336 & 0.342 & 0.448 & 0.390 & 0.212 & 0.183 & 0.899 & 0.552 & 0.212 & 0.194 & 19758 & 0.187 & 0.299 & 0.37 & 0.539 & 0.521 & 0.275 & 0.187 & ${ }^{\circ}$ & 0.287 & 0.656 & 0.010 \\
\hline & 0.343 & 0.044 & 0.208 & 0.156 & 0.125 & 0.328 & 0.075 & 21.523 & 0.085 & 0.423 & 0.198 & 0.246 & 0.109 & 1.538 & 16.311 & 1.156 & 0.099 & 0.367 & 0.208 & 0.161 & 0.134 & 1.241 & . & 1558 & 0.028 \\
\hline net & 0.594 & 0.162 & 0.43 & 0.482 & 0.614 & 2203 & 0.235 & 1.778 & 0.158 & 1.161 & 0.856 & 0.218 & 0.163 & 0.498 & 1.125 & 24.692 & 0.418 & 0.697 & 1.115 & 0.255 & 0.174 & 0.683 & 1925 & 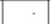 & 0.01 \\
\hline & 0.108 & 0.238 & 0.043 & 0.029 & 0.039 & 0.018 & 0.020 & 0.019 & 0.026 & 0.058 & 0.019 & 0.055 & 0.027 & 0.094 & 0.019 & 0.020 & 0.025 & 0.030 & 0.023 & 0.062 & 0.036 & 0.030 & 0.024 & 0.018 & \\
\hline
\end{tabular}

Notes: Grey column indicates intra-island migration. Source: Author's calculations

Table 9 Multiplicative component matrix of tertiary-educated migration, 2010

\begin{tabular}{|c|c|c|c|c|c|c|c|c|c|c|c|c|c|c|c|c|c|c|c|c|c|c|c|c|c|}
\hline 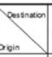 & 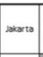 & 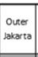 & senare & ensasere & srrosere & Devereser & meson & matescos & 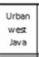 & 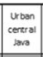 & $\begin{array}{c}\text { ulowo } \\
\text { eas } \\
\text { smon }\end{array}$ & 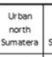 & $\begin{array}{c}\text { trom } \\
\text { samen } \\
\text { sumber }\end{array}$ & 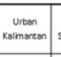 & 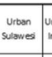 & 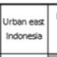 & 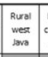 & 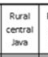 & 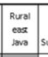 & 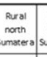 & 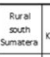 & $\begin{array}{c}\text { Ruval } \\
\text { volmmeran }\end{array}$ & $\begin{array}{c}\text { Rural } \\
\text { subares }\end{array}$ & 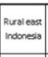 & $\begin{array}{l}\text { ortem } \\
\text { comp. }\end{array}$ \\
\hline beroso & & 3.258 & 0.983 & 0.58 & 0.005 & 0.727 & 0.694 & 0.5654 & 0.783 & 0.522 & 0.288 & 0.706 & 0.858 & 0.427 & 0.523 & 0.556 & 0.729 & \begin{tabular}{|l|}
0.359 \\
\end{tabular} & 0.27 & 0.307 & 0.350 & 0.273 & \begin{tabular}{l|l}
0.225 \\
\end{tabular} & 0.356 & 0.179 \\
\hline Onters & 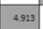 & & 212 & 0.784 & 0.45 & 0.056 & 0.582 & 0.998 & 20201 & osesent & 0.400 & 0,727 & 0.979 & 0.621 & 0.437 & 0.521 & 2611 & \begin{tabular}{|l|l|}
0.87 \\
\end{tabular} & 0.6080 & 0.450 & 0.663 & 0.385 & 0.24 & 0.376 & 0.005 \\
\hline Barares & 2187 & 1003 & & 0549 & 0.226 & 0764 & 0.683 & 0.532 & 4486 & 0.6000 & \begin{tabular}{|l|l|}
0.324 \\
\end{tabular} & |0.938 & 1366 & 0.866 & 0.541 & 0.545 & \begin{tabular}{|l|l|} 
\\
\end{tabular} & \begin{tabular}{|l|l|l|l|} 
\\
\end{tabular} & \begin{tabular}{|l|l|l}
0355 \\
\end{tabular} & 0.397 & 0.665 & 0.392 & 0.309 & 0.488 & 0.057 \\
\hline sersorese & 1396 & 0.652 & 0.819 & & 0.919 & 0.792 & 0.381 & 0.455 & 0.052 & 4006 & 0.510 & 0.665 & 0.668 & 0.909 & 0.474 & 0.729 & 0.628 & \begin{tabular}{|l|l|} 
\\
\end{tabular} & 0.0800 & 0.232 & 0.479 & 0.825 & 0.281 & 0.593 & 0.035 \\
\hline Sratore & 1265 & 0.542 & 0.005 & 1028 & & 2273 & 0.344 & 0.965 & 0.225 & o.rog & 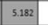 & 0.623 & 0.0202 & 1.750 & 0.958 & 1.626 & 0.995 & \begin{tabular}{|l|}
0.597 \\
\end{tabular} & 27397 & 0.163 & 0.210 & 0.834 & 0.407 & 1315 & 0.003 \\
\hline 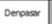 & 1005 & 0.427 & 0923 & 09916 & 1878 & & 0504 & 0.877 & 0.195 & $12 \times 7$ & 27856 & . 0355 & 0.417 & 0.823 & 1.293 & 3.926 & 0.273 & \begin{tabular}{|l|}
0.327 \\
\end{tabular} & \begin{tabular}{|l|l}
6451 \\
\end{tabular} & 0.103 & 0.27 & 0.423 & 0.688 & 3309 & 0.008 \\
\hline Mesonon & $0.9 \mathrm{ses}$ & 0.997 & 0.660 & 0.180 & 0.166 & 0.252 & & 0.190 & 0.225 & 0.249 & 0.104 & 6296 & 0879 & 0.439 & 0.193 & 0.902 & \begin{tabular}{|l|}
0.217 \\
\end{tabular} & \begin{tabular}{|l|}
0.0089 \\
\end{tabular} & \begin{tabular}{|l|l|l|} 
\\
\end{tabular} & 6.081 & 0.671 & 0.517 & 0.067 & 0.173 & 0.008 \\
\hline 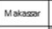 & $\begin{array}{ll}0.003 \\
\end{array}$ & 0.139 & 0.343 & 0.153 & 0.397 & 0.249 & 0.12 & & 0.080 & 0.27 & \begin{tabular}{|l|l|l|l|l} 
\\
\end{tabular} & 02266 & 0127 & 1220 & 7.052 & 2396 & \begin{tabular}{|l|l|}
0.058 \\
\end{tabular} & \begin{tabular}{|l|l|}
0.065 \\
\end{tabular} & \begin{tabular}{|l|l|l} 
\\
\end{tabular} & 0.025 & 0.051 & 0.850 & 11338 & 248 & 0.036 \\
\hline & 1550 & 1312 & 5259 & 0.657 & 0.456 & 0.322 & 0.292 & 0.354 & & 0.58 & 0.350 & 0.381 & 0.751 & 0.421 & 0.197 & 0.300 & 8558 & \begin{tabular}{|l|l|}
0837 \\
\end{tabular} & $\mid 0.8252$ & 0.208 & 0.427 & 0.288 & 0.132 & 0.170 & 0.017 \\
\hline & 12800 & 0.733 & 0.856 & 3888 & 0.702 & 0.784 & 0.360 & 0.411 & 1003 & & 0.661 & 0.750 & 1.126 & 12276 & 0.501 & 0.970 & 0.950 & \begin{tabular}{|l|l|}
5.662 \\
\end{tabular} & \begin{tabular}{|l|l|}
12208 \\
\end{tabular} & 0.315 & 0.979 & 0.950 & 0.361 & 0.932 & 0.088 \\
\hline & 0.872 & 0.225 & 0.524 & 0.558 & 7228 & .6666 & 0.112 & 0.031 & 0.374 & \begin{tabular}{|l|l|l} 
& 0.68 \\
\end{tabular} & & 0.2293 & 0.274 & 1.535 & 0.058 & 1.251 & $|0.281|$ & \begin{tabular}{|l|}
0.439 \\
\end{tabular} & 10700 & 0.103 & 0.270 & $0.8 \mathrm{est}$ & 0.292 & 1991 & 0.020 \\
\hline trescos & 0.824 & 0.396 & 0.005 & 0.258 & 0.172 & 0.203 & 4.116 & 0.221 & 0.250 & 042 & \begin{tabular}{|l|l|l|} 
\\
\end{tabular} & & 12,20 & 0.332 & 0.122 & 0.181 & 0.241 & \begin{tabular}{|l|l|}
0.166 \\
\end{tabular} & \begin{tabular}{|l|l|l}
0211 \\
\end{tabular} & 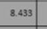 & & & 0.069 & .094 & 0.057 \\
\hline & 1.081 & 0.484 & 1.062 & 0.486 & 0.238 & 0.198 & 0900 & 0.187 & 0.512 & \begin{tabular}{|l|l|}
0.64 \\
\end{tabular} & \begin{tabular}{|l|l|l|} 
\\
\end{tabular} & 12142 & & 0.988 & 0.189 & \begin{tabular}{l|l} 
\\
\end{tabular} & \begin{tabular}{|l|}
0.489 \\
\end{tabular} & \begin{tabular}{|l|l|}
0.240 \\
\end{tabular} & 0.239 & 0.537 & 12455 & 0.232 & 0.081 & 0.093 & 0.041 \\
\hline & 0.480 & 0.487 & 0.597 & 0.524 & 0.810 & 0.252 & 0.236 & 1.001 & 0.170 & 0.874 & $\mid 0.796$ & 0244 & 0282 & & 0.626 & 0.301 & \begin{tabular}{|l|l|l|} 
\\
\end{tabular} & \begin{tabular}{|l|}
0.218 \\
\end{tabular} & \begin{tabular}{|l|l|l|} 
& 0.55 \\
\end{tabular} & 0.112 & 0.120 & 34.875 & 0.542 & 0.165 & 0.090 \\
\hline & 0.049 & 0.445 & 0.332 & 0.297 & 0.315 & 0.959 & 0.070 & 5.217 & 0.121 & 0.43 & 0.254 & 0.167 & 0.137 & 0.670 & & \begin{tabular}{|l|l|}
1591 \\
\end{tabular} & \begin{tabular}{|l|l|} 
\\
\end{tabular} & \begin{tabular}{|l|}
0.0911 \\
\end{tabular} & \begin{tabular}{|l|l|}
0.188 \\
\end{tabular} & 0.051 & 0.044 & 0.427 & 15.067 & 1552 & 0.025 \\
\hline soneso & 0.295 & 0.439 & 0.425 & 0.822 & 0.514 & 0934 & 0.107 & 1.853 & 0.139 & 0.700 & \begin{tabular}{|l|l|l|} 
\\
\end{tabular} & 0.899 & 0.153 & 0.321 & 0.956 & & \begin{tabular}{|c|}
0.128 \\
\end{tabular} & \begin{tabular}{|l|l|l|} 
\\
\end{tabular} & \begin{tabular}{|l|l|l|l} 
\\
\end{tabular} & 0.045 & 0.055 & 0.266 & 0.470 & 17,687 & 0.021 \\
\hline & 1001 & 1.509 & 6550 & 0.855 & 0285 & 0.256 & 0.181 & 0.224 & 6952 & 0.60 & | 0.155 & 02993 & 0.827 & 0.507 & 0.183 & 0.196 & & . 0580 & \begin{tabular}{|l|l|l} 
\\
\end{tabular} & 0.160 & 2.435 & 0.385 & 0.101 & 2185 & 0.029 \\
\hline & 1007 & 0.759 & 0.814 & 478 & 0.78 & 0433 & 0.173 & 0.178 & 0.951 & 6013 & \begin{tabular}{|l|l|}
0.432 \\
\end{tabular} & 0.412 & 0.47 & 0.688 & 0.259 & 0.439 & $|0,000|$ & & 1076 & 0.221 & 0.570 & 0.848 & 0.125 & 0.384 & 0.053 \\
\hline 100 & 0.059 & \begin{tabular}{|l|l}
0374 \\
\end{tabular} & 0.040 & 0,011 & 7191 & 53800 & 0.48 & 0.3854 & 0.366 & 1012 & \begin{tabular}{|l|l|l|} 
\\
\end{tabular} & 0.464 & 0.318 & 1354 & 0.407 & 1.099 & \begin{tabular}{|l|}
0.435 \\
\end{tabular} & \begin{tabular}{|l|l|}
0.874 \\
\end{tabular} & . & 0.185 & 0.388 & 1.205 & 0.275 & 1087 & 0.064 \\
\hline semerefer & 0.559 & 0.9011 & 0.551 & 0.185 & 0.123 & 0.151 & 11975 & 0.114 & 0.229 & 0.403 & \begin{tabular}{|l|l|} 
\\
\end{tabular} & 8498 & 0.552 & 0.264 & $0.07 \pi$ & \begin{tabular}{l|l} 
\\
\end{tabular} & \begin{tabular}{|l|}
0.289 \\
\end{tabular} & \begin{tabular}{|l|}
0.175 \\
\end{tabular} & \begin{tabular}{|l|l|l} 
& 0.17
\end{tabular} & . & 1318 & 0.479 & 0.076 & 0.990 & 0.038 \\
\hline & 0.769 & 0.496 & 0.833 & $0<42$ & 0.172 & 0.240 & 0.223 & 0.127 & 0.529 & \begin{tabular}{|l|} 
\\
\end{tabular} & 0.225 & 0.863 & 165021 & 0.219 & 0.118 & \begin{tabular}{l|l}
0.188 \\
\end{tabular} & \begin{tabular}{|l|l|} 
\\
\end{tabular} & \begin{tabular}{|l|}
0.499 \\
\end{tabular} & \begin{tabular}{|l|l|l} 
\\
\end{tabular} & 0.902 & $\cdot$ & 0.285 & 0.097 & o.111 & 0.020 \\
\hline & 0.617 & 0.260 & 0.617 & 0.761 & 0.028 & 0.299 & 0.277 & 0.768 & 0.200 & 1052 & 0.645 & 0.223 & 0.261 & 17.678 & 0.288 & 0.271 & \begin{tabular}{|l|}
0.363 \\
\end{tabular} & \begin{tabular}{|l|}
0.239 \\
\end{tabular} & \begin{tabular}{|l|l|l} 
\\
\end{tabular} & 0.284 & 0.288 & & 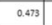 & 0.242 & 0.016 \\
\hline noes & 0.220 & 0.095 & 0.236 & 0.230 & 0.208 & 0.179 & 0.057 & 19.021 & 0.0088 & 0.390 & & 0.2 & & 1.402 & 17.108 & \begin{tabular}{l|l}
1.599 \\
\end{tabular} & \begin{tabular}{|l|}
0.063 \\
\end{tabular} & \begin{tabular}{|l|l|}
0.120 \\
\end{tabular} & \begin{tabular}{|l|l|}
0.195 \\
\end{tabular} & 148 & 96 & 2003 & & 2648 & 0.021 \\
\hline & 0.558 & 0.661 & 0.596 & 0.767 & 0.946 & 2244 & 0.174 & 0.305 & 0.195 & 1521 & |.1.15s & 0.230 & 0.176 & 0.514 & 1.005 & 19225 & $0.200 \mid$ & \begin{tabular}{|l|}
0.379 \\
\end{tabular} & 1227 & 0.118 & 0.121 & 0.656 & 0.745 & & 0.016 \\
\hline & 0.099 & 0.197 & 0.033 & 0.021 & 0.029 & 00218 & 0.015 & \begin{tabular}{|l|l|} 
\\
\end{tabular} & 0.029 & \begin{tabular}{|l|l|} 
\\
\end{tabular} & \begin{tabular}{|l|}
0.025 \\
\end{tabular} & 0.059 & 0.092 & 0.0055 & 0.020 & 0.033 & $\mid 0.018$ & \begin{tabular}{|l|}
0.029 \\
\end{tabular} & \begin{tabular}{|l|}
$\mid 0.025$ \\
\end{tabular} & 0.055 & 0.041 & 0.044 & 0.042 & 0,0000 & \\
\hline
\end{tabular}

Notes: Grey column indicates intra-island migration. Source: Author's calculations 
Acknowledgements This research is supported by an Australian Government Research Training Program (AGRTP) Scholarship. The author would like to thank James Raymer for his comments and suggestions on various versions of this paper

Authors' contributions Not applicable.

Funding Open Access funding enabled and organized by CAUL and its Member Institutions.

Data availability Secondary data were obtained from Australian Data Archive, Australian National University. Derived data supporting the findings of this study are available within this article.

Code availability Not applicable.

\section{Declarations}

Conflict of interest The author declares that there is no conflict of interest.

Open Access This article is licensed under a Creative Commons Attribution 4.0 International License, which permits use, sharing, adaptation, distribution and reproduction in any medium or format, as long as you give appropriate credit to the original author(s) and the source, provide a link to the Creative Commons licence, and indicate if changes were made. The images or other third party material in this article are included in the article's Creative Commons licence, unless indicated otherwise in a credit line to the material. If material is not included in the article's Creative Commons licence and your intended use is not permitted by statutory regulation or exceeds the permitted use, you will need to obtain permission directly from the copyright holder. To view a copy of this licence, visit http://creativecommons.org/licen ses/by/4.0/.

\section{References}

Abel, G. J., \& Sander, N. (2014). Quantifying global international migration flows. Science, 343(6178), 1520-1522. https://doi.org/10.1126/science.1248676

Adietomo, S. M., Posselt, H., \& Utomo, A. (2014). Youth in Indonesia. UNFPA Indonesia. https://indon esia.unfpa.org/sites/default/files/pub-pdf/BUKU_Monograph_No2_Youth_in_Indonesia_ENG_05_ Low-res.pdf

Arifin, E. N., Ananta, A., Utami, D. R. W. W., Handayani, N. B., \& Pramono, A. (2015). Quantifying Indonesia's ethnic diversity. Asian Population Studies, 11(3), 233-256. https://doi.org/10.1080/ 17441730.2015 .1090692

Bernard, A., \& Bell, M. (2018). Educational selectivity of internal migrants: A global assessment. Demographic Research, 39(29), 835-854. https://doi.org/10.4054/DemRes.2018.39.29

Bjarnason, T., \& Edvardsson, I. R. (2017). University pathways of urban and rural migration in Iceland. Journal of Rural Studies, 54, 244-254. https://doi.org/10.1016/j.jrurstud.2017.07.001

Charles-Edwards, E., Muhidin, S., Bell, M., \& Zhu, Y. (2016). Migration in Asia. In M. J. White (Ed.), International handbook of migration and population distribution (pp. 269-284). Springer Science+Business Media Dordrecht.

Charles-Edwards, E., Bell, M., Bernard, A., \& Zhu, Y. (2017). Internal migration in the countries of Asia: Levels, ages, and spatial impacts. http://www.asianmc.org/wp-content/uploads/2017/10/ ADRI_Working_Paper_Internal_Migration_in_Asia_Final.pdf

Corcoran, J., Faggian, A., \& Mccann, P. (2010). Human capital in remote and rural Australia: The role of graduate migration. Growth \& Change, 41(2), 192-220. https://doi.org/10.1111/j.1468-2257.2010. 00525. $\mathrm{x}$

Crescenzi, R., Holman, N., \& Orru, E. (2017). Why do they return? Beyond the economic drivers of graduate return migration. The Annals of Regional Science, 59(3), 603-627. https://doi.org/10.1007/ s00168-016-0762-9 
Engbersen, G., \& Snel, E. (2013). Liquid migration: Dynamic and fluid patterns of post-accession migration flows. In B. Glorious, I. Grabowska-Lusinska, \& A. Kuvik (Eds.), Mobility in transition: Migration patterns after EU enlargement (pp. 21-40). Amsterdam University Press.

Fafchamps, M., \& Shilpi, F. (2013). Determinants of the choice of migration destination. Oxford Bulletin of Economics and Statistics, 75(3), 388-409. https://doi.org/10.1111/j.1468-0084.2012.00706.x

Faggian, A., Comunian, R., \& Li, Q. C. (2014). Interregional migration of human creative capital: The case of "Bohemian graduates." Geoforum, 55, 33-42. https://doi.org/10.1016/j.geoforum.2014.05. 003

Fielding, A. J. (1992). Migration and social mobility: South East England as an escalator region. Regional Studies, 26(1), 1-15. https://doi.org/10.1080/00343409212331346741

Findlay, A., Mason, C., Houston, D., McCollum, D., \& Harrison, R. (2009). Escalators, elevators, and travelators: The occupational mobility of migrants to South-East England. Journal of Ethnic and Migration Studies, 35(6), 861-879. https://doi.org/10.1080/13691830902957676

Gould, W. T. S. (1982). Education and internal migration: A review and report. International Journal of Educational Development, 1(3), 103-111. https://doi.org/10.1016/0738-0593(82)90047-5

He, Z., Zhai, G., Asami, Y., \& Tsuchida, S. (2016). Migration intentions and their determinants: Comparison of college students in China and Japan. Asian and Pacific Migration Journal, 25(1), 62-84. https://doi.org/10.1177/0117196815621203

Jones, G., \& Mulyana, W. (2015). Urbanization in Indonesia. UNFPA Indonesia. https://indonesia.unfpa. org/sites/default/files/pub-pdf/FA_Isi_BUKU_Monograph_No.4_URBANIZATION_.pdf

Jones, G. W., Rangkuti, H., Utomo, A., \& McDonald, P. (2016). Migration, ethnicity, and the educational gradient in the Jakarta mega-urban region: A spatial analysis. Bulletin of Indonesian Economic Studies, 52(1), 55-76. https://doi.org/10.1080/00074918.2015.1129050

Liu, Y., Shen, J., Xu, W., \& Wang, G. (2017). From school to university to work: Migration of highly educated youths in China. The Annals of Regional Science, 59(3), 651-676. https://doi.org/10.1007/ s00168-016-0753-x

Lomax, N., Stillwell, J., Norman, P., \& Rees, P. (2014). Internal migration in the United Kingdom: Analysis of an estimated inter-district time series, 2001-2011. Applied Spatial Analysis and Policy, 7(1), 25-45. https://doi.org/10.1007/s12061-013-9098-3

Long, L. H. (1973). Migration differentials by education and occupation: Trends and variations. Demography, 10(2), 243-258. https://doi.org/10.2307/2060816

Maddox, B. (2010). Marginal returns: re-thinking mobility and educational benefit in contexts of chronic poverty. Compare: A Journal of Comparative and International Education, 40(2), 213-222. https:// doi.org/10.1080/03057920903546070

Malamassam, M.A. (2016). Youth migration in Indonesia: Decision to move and to choose destination areas. Indonesian Journal of Geography, 48(1), 62-72. https://doi.org/10.22146/ijg.12469

Malamassam, M.A., Setiawan, B., Latifa, A., \& Hidayati, I. (2018). Migrasi tenaga kerja berpendidikan tinggi dan kontribusinya terhadap pembangunan sumber daya manusia: Kasus Kota Sorong. Pusat Penelitian Kependudukan LIPI.

Martel, C., Carson, D., \& Taylor, A. (2013). Changing patterns of migration to Australia's Northern Territory: Evidence of new forms of escalator migration to frontier regions? Migration Letters, 10(1), 101-113. https://doi.org/10.33182/ml.v10i1.115

McDonald, P., Utomo, I. D., Utomo, A., Reimondos, A., \& Hull, T. (2013). Migration and transition to adulthood: Education and employment outcomes among young migrants in Greater Jakarta. Asian Population Studies, 9(1), 4-27. https://doi.org/10.1080/17441730.2012.736700

Muhidin, S. (2018). An analysis of the relationship between internal migration and education in Indonesia. https://unesdoc.unesco.org/ark:/48223/pf0000266053

Rangkuti, H. (2016). Migration out of Central Java: 1971-2010 [Ph.D. thesis, Australian National University, Canberra].

Raymer, J., Bonaguidi, A., \& Valentini, A. (2006). Describing and projecting the age and spatial structures of interregional migration in Italy. Population, Space and Place, 12(5), 371-388. https://doi. org/10.1002/psp.414

Raymer, J., de Beer, J., \& van der Erf, R. (2011). Putting the pieces of the puzzle together: Age and sex-specific estimates of migration amongst countries in the EU/EFTA, 2002-2007. European 
Journal of Population / Revue Européenne De Démographie, 27(2), 185-215. https://doi.org/10. 1007/s10680-011-9230-5

Raymer, J., \& Rogers, A. (2007). Using age and spatial flow structures in the indirect estimation of migration streams. Demography, 44(2), 199-223. www.jstor.org/stable/4137252

Rebhun, U., \& Brown, D. (2015). Patterns and selectivities of urban/rural migration in Israel. Demographic Research, 33, 113-143. https://doi.org/10.4054/DemRes.2015.33.5

Rogers, A., \& Castro, L. J. (1981). Model migration schedules. http://pure.iiasa.ac.at/id/eprint/1543/1/ RR-81-030.pdf

Rogers, A., Willekens, F., Little, J., \& Raymer, J. (2002). Describing migration spatial structure. Papers in Regional Science, 81(1), 29-48. https://doi.org/10.1111/j.1435-5597.2002.tb01220.x

Rosenbloom, J. L., \& Sundstrom, W. A. (2004). The decline and rise of interstate migration in the United States: Evidence from the IPUMS, 1850-1990. In A. J. Field (Ed.), Research in economic history (Vol. 22, pp. 289-325). Elsevier. https://doi.org/10.1016/S0363-3268(04)22006-7

Ryan, L. (2011). Migrants' social networks and weak ties: Accessing resources and constructing relationships post-migration. The Sociological Review, 59(4), 707-724. https://doi.org/10.1111/j.1467954X.2011.02030.x

Shryock, H. S., \& Nam, C. B. (1965). Educational selectivity of interregional migration. Social Forces, 43(3), 299-310. https://doi.org/10.2307/2574759

Smith, D. P., Rérat, P., \& Sage, J. (2014). Youth migration and spaces of education. Children's Geographies, 12(1), 1-8. https://doi.org/10.1080/14733285.2013.871801

Spring, A., Tolnay, S. E., \& Crowder, K. (2016). Moving for opportunities? Changing patterns of migration in North America. In M. J. White (Ed.), International handbook of migration and population distribution (pp. 421-448). Springer Science+Business Media Dordrecht.

Statistics Indonesia. (2011a). Kewarganegaraan, suku bangsa, agama, dan bahasa sehari-hari penduduk Indonesia: Hasil Sensus Penduduk 2010. BPS - Statistics Indonesia.

Statistics Indonesia. (2011b). Umur dan jenis kelamin penduduk Indonesia: Hasil Sensus Penduduk 2010. BPS - Statistics Indonesia.

Statistics Indonesia. (2016). Statistics of migration Indonesia: Results of the 2015 Intercensal Population Survey. BPS - Statistics Indonesia.

Stockdale, A., \& Catney, G. (2014). A life course perspective on urban-rural migration: The importance of the local context. Population, Space and Place, 20, 83-98. https://doi.org/10.1002/psp.1758

Sukamdi, \& Mujahid, G. (2015). Internal migration in Indonesia. UNFPA Indonesia. https://indonesia. unfpa.org/sites/default/files/pub-pdf/FA_Isi_BUKU_Monograph_Internal_Migration_ENG.pdf

Suzuki, Y., \& Suzuki, Y. (2016). Interprovincial migration and human capital formation in China. Asian Economic Journal, 30(2), 171-195. https://doi.org/10.1111/asej.12089

Tirtosudarmo, R. (2009). Mobility and human development in Indonesia. United Nations Development Programme. http://hdr.undp.org/sites/default/files/hdrp_2009_19.pdf

Venhorst, V. A., Van Dijk, J., \& Van Wissen, L. (2010). Do the best graduates leave the peripheral areas of the Netherlands. Tijdschrift Voor Economische En Sociale Geografie, 101(5), 521-537. https:// doi.org/10.1111/j.1467-9663.2010.00629

Venhorst, V. A. (2013). Graduate migration and regional familiarity. Tijdschrift Voor Economische En Sociale Geografie, 104(1), 109-119. https://doi.org/10.1111/tesg.12000

Vidyattama, Y. (2016). Inter-provincial migration and 1975-2005 regional growth in Indonesia. Papers in Regional Science, 95(S1), S87-S105. https://doi.org/10.1111/pirs.12120

Wajdi, N., Van Wissen, L.J., \& Mulder, C.H. (2015). Interregional flows in Indonesia. Sojourn: Journal of Social Issues in Southeast Asia, 30(2), 371-442. www.jstor.org/stable/24779959

Wajdi, N., Adioetomo, S. M., \& Mulder, C. H. (2017a). Gravity models of interregional migration in Indonesia. Bulletin of Indonesian Economic Studies, 53(3), 309-332. https://doi.org/10.1080/00074 918.2017.1298719

Wajdi, N., Mulder, C. H., \& Adioetomo, S. M. (2017b). Inter-regional migration in Indonesia: A micro approach. J Pop Research, 34, 253-277. https://doi.org/10.1007/s12546-017-9191-6

Whisler, R. L., Waldorf, B. S., Mulligan, G. F., \& Plane, D. A. (2008). Quality of life and the migration of the college-educated: A life course approach. Growth Change, 39, 58-94. https://doi.org/10. $1111 / \mathrm{j} .1468-2257.2007 .00405 . \mathrm{x}$ 
Williams, N. (2009). Education, gender, and migration in the context of social change. Social Science Research, 38(4), 883-896. https://doi.org/10.1016/j.ssresearch.2009.04.005

Wilson, T. (2015). The impact of education-bound mobility on inter-regional migration age profiles in Australia. Applied Spatial Analysis and Policy, 8(4), 371-391. https://doi.org/10.1007/ s12061-014-9124-0

World Bank (2003). Decentralising Indonesia: A regional public expenditure review overview report. https://openknowledge.worldbank.org/handle/10986/14632

World Bank (2006). Teacher employment and deployment in Indonesia: Opportunities for equity, efficiency and quality improvement. https://openknowledge.worldbank.org/handle/10986/8110

Publisher's Note Springer Nature remains neutral with regard to jurisdictional claims in published maps and institutional affiliations. 